\title{
EL ROL DE LA TEORÍA LITERARIA EN LA REVISTA CHILENA DE LITERATURA: ESTUDIO DIACRÓNICO-DESCRIPTIVO Y CRÍTICO DE LOS NOVENTA Y OCHO NÚMEROS PUBLICADOS
}

\author{
Sergio Carumán \\ Universidad de Chile \\ Santiago de Chile, Chile \\ scaruman@uchile.cl \\ David Wallace \\ Universidad de Chile \\ Santiago de Chile, Chile \\ dwallaceuchile@gmail.com
}

\begin{abstract}
RESUMEN / ABSTRACT
Este artículo propone una revisión indagatoria, panorámica y sumaria de las principales corrientes, modelos y teorías de la literatura que aparecen implicadas en los artículos de los noventa y ocho números publicados de la Revista Chilena de Literatura $(R C h L)$. Se trata de un estudio diacrónico-descriptivo y crítico, efectuado a partir de la metodología del análisis de contenido, de acuerdo con el modelo de Klaus Krippendorf, cuya finalidad es rastrear y mapear dichas corrientes y tendencias a fin de dar no solo una imagen global del estado de la cuestión referida a la teoría literaria y su participación en la formulación de los artículos de la revista, sino también emitir juicios críticos sobre estas distintas aproximaciones. Se trata de un estudio transversal, de carácter histórico, que pretende filiar los artículos a las diversas tradiciones teóricas, críticas y especulativas acerca de los estudios literarios presentes en la $R C h L$.

Palabras clave: teoría literaria; Revista Chilena de Literatura, crítica literaria, análisis de contenido, diacronía.
\end{abstract}


THE ROLE OF LITERARY THEORY IN THE REVISTA CHILENA DE LITERATURA:

DIACHRONIC STUDY - DESCRIPTIVE AND CRITICAL OF THE NINETY-EIGHT ISSUES PUBLISHED

This article proposes an exploratory, panoramic and summary review of the main currents, models, and theories of literature that appear in the articles of the ninety-eight published issues of Revista Chilena de Literatura. This is a diachronic, descriptive, and critical study that follows a content analysis methodology set by Klaus Krippendorf's model. The purpose of this model is to track and map these trends in order to give not only a global image of the state of the matter related to the literary theory and its participation in the formulation of the articles of the magazine, but also to set forth critical views on these approaches. This is a cross-sectional study of historical nature, which aims to link the articles to the various theoretical, critical and speculative traditions about literary studies developed in RChL.

KEYWORDS: literary theory, Revista Chilena de Literatura, Literary criticism, content analysis, diachrony.

Recepción: 04/04/2019

Aprobación: 15/06/2019

In memoriam:

Lucía Invernizzi Santa Cruz,

"por ser vos quien sois".

\section{INVENTIO: INTRODUCCIÓN}

El presente artículo tiene por objetivo una revisión panorámica y sumaria de la presencia de las diversas tendencias, corrientes y modelos de la teoría literaria en los 98 números publicados de la Revista Chilena de Literatura $(R C h L)$. Se trata de comprender el probable modelamiento que la teoría literaria ha impreso a los estudios literarios representados por los artículos de la revista a lo largo de sus cuarenta y nueve años de existencia, y sus casi cien números publicados.

Para todos los efectos de esta investigación, entenderemos la teoría literaria como un campo de estudios cuyo objeto propio es la literatura, a pesar de que no exista una definición unívoca de esta (Culler 2014, Eagleton1994:11-28, Estébanez, Fokkema e Ibsch, Marchese y Forradellas 246-249, Segre, Selden, etc.), sino diversas aproximaciones derivadas de perspectivas epistemológicas y metodológicas de muy variada naturaleza (Todorov), que privilegian los diversos aspectos o fenómenos susceptibles de ser estudiados en los textos 
y el discurso literario (Brioschi y Di Girolamo). Así, es posible encontrar en la teoría literaria contemporánea perspectivas ancladas en la filosofía (Asensi 1998), la estética (Bayer), el texto como estructura (Culler1978), el habla literaria como rasgo distintivo (Barthes 1993, 2015; Dubois; Greimas 7-21), el texto como modelamiento discursivo (van Dijk, Texto y contexto 147-238; van Dijk La ciencia del texto 141-173; van Dijk "Pragmática de la comunicación literaria" 171-194), el lenguaje como figuración (de Man 1990), el contexto histórico (Angenot, Rama, Viñas), la presencia del emisor o autor (Barthes, Segre), el rol del lector (Iser 29-51; Rall, Warning), el contexto de recepción (Asensi 2003: 651-688, Jauss 289-296; Rall, Warning), el lenguaje como desarticulación (Culler 1992), etc.

Cualquiera sea la perspectiva, el modelo o la metodología adoptada, entenderemos por teoría literaria la inscripción de algunos de estos parámetros en la redacción de los artículos de la $R C h L$, fundamentalmente expresados a partir de los conceptos propios de cada una de estas variables. Así, todos los artículos analizados incluyen alguna noción referente al modo cómo se concibe, analiza y/o interpreta la literatura, los textos literarios o el discurso que lo conforma, los objetos que la constituyen como un campo disciplinario de las humanidades, sus relaciones o conexiones explícitas o implícitas con otros campos disciplinarios (historia, sociología, psicología, política, etc.), la indagación acerca de los alcances y límites epistemológicos o metodológicos de estos mismos estudios, la condición metaliteraria de ciertos textos o la propia conciencia autorreflexiva de los estudios literarios en las variantes genéricas y textuales establecidas por la academia como una de las instituciones encargadas de comprender, analizar e interpretar la literatura en la pluralidad de sus manifestaciones.

En el caso específico de la $R C h L$, entendemos, además, que esta conceptualización de la teoría literaria ha sido también la vocería o la línea editorial del propio Departamento de Literatura de la Facultad de Filosofía y Humanidades de la Universidad de Chile ${ }^{1}$ : ¿cómo piensa o ha pensado la

De hecho, en la página web de la $R C h L$ (https://revistaliteratura.uchile.cl/) aparece la referencia a SJR (https:/www.scimagojr.com/journalsearch.php?q=6100153026\&tip=sid\&e xact=no), en la que se declara la adscripción de la revista al segmento Q1, y a los descriptores: Literatura y Teoría Literaria, ocupando el lugar 108 del ranking (2017) en el área de Artes y Humanidades, siendo solo superada por la revista Signos (95 en el ranking 2017), en el caso de Chile, y que más bien trabaja con temas de lingüística, semiótica y discurso, antes que con temas propios de la literatura o de la teoría literaria. La indexación de la $R C h L$, además, 
literatura esta entidad? ¿Desde qué lugar teórico se la plantea como objeto de estudio? ¿Qué rasgos o características la definen o caracterizan? ¿Qué corrientes de estudio principales lideran estos estudios? ¿Cómo se posiciona la literatura con relación a la cultura, la educación, la política, las propias humanidades? Todas estas cuestiones deberían emerger como resultantes de inferencias de segundo orden con relación a esta investigación, especialmente en lo concerniente a la batería de conceptos que informan y conforman los estudios literarios en este Departamento desde 1970 a la fecha, y cuyas representaciones textuales y discursivas encontraremos, precisamente, en los artículos de la revista.

Una investigación de estas características tampoco es ajena al contexto histórico o de producción de los textos establecidos como unidades de registro (los artículos o estudios publicados), puesto que las circunstancias históricas han determinado lineamientos editoriales, privilegio de ciertas perspectivas teóricas sobre otras, elección de objetos de estudio, derivación de conclusiones o interpretaciones válidas, proyección de metodologías o, simplemente, ausencias y elisiones de temas, en algún momento vetados, censurados o políticamente incorrectos. En este sentido, de hecho, solo desde el punto de vista de la continuidad histórica de los números, es posible observar un vacío o salto en la periodización, producto de la intervención de la dictadura en 1973, que abarca hasta el año 1976, donde se retoma la publicación de la revista, con un solo número para ese año. De igual modo, el registro de las sucesivas direcciones de la revista, o la constitución del comité editorial, son indicativos de las líneas de desarrollo disciplinario que se fueron estableciendo a lo largo del tiempo.

\section{DISPOSITIO: METODOLOGÍA}

Hemos adoptado un modelo de análisis propio de los grandes volúmenes de información, y cuyo desarrollo metodológico avala la perspectiva panorámica de esta revisión (Krippendorf). En este sentido, y de acuerdo con este modelo, hemos seleccionado como unidades de contexto cada uno de los 98 números publicados de la $R C h L$, fijando como unidad temática la elección de un 
artículo, en el entendido de que representa algún enfoque, corriente o modelo de la teoría literaria en su formulación. Inmediatamente a continuación, hemos procedido a un muestreo en etapas múltiples, en tanto variable del muestreo por conglomerados. Así, la muestra total ${ }^{2}$, esto es, los 98 números de la $R C h L$, fueron segmentados en cuatro grupos, según un procedimiento de división arbitraria, en cuatro tramos:

- $\quad$ primer tramo (T-1), del número $\left(\mathrm{N}^{\circ}\right) 1$ al 25 , entre 1970 y $1985 ; 25$ unidades;

- $\quad$ segundo tramo (T-2), $\mathrm{N}^{\circ} 26$ al 50, entre 1985 y 1997; 25 unidades;

- $\quad$ tercer tramo (T-3), $\mathrm{N}^{\circ} 51$ al 75, entre 1997 y 2009; 25 unidades;

- cuatro tramo (T-4), N76 al 98, entre 2010 y 2018; 23 unidades.

La arbitrariedad de la segmentación obedece al criterio de búsqueda de patrones de contenido, esto es, agrupaciones de conceptos que sean referenciales con relación a un origen epistemológico rastreable en las principales líneas o corrientes de la teoría literaria contemporánea. Como la publicación del primer número de la $R C h L$ se efectúa en 1970, la primera asunción hipotética de contenido, en virtud de su posicionamiento epocal, es la presencia de rasgos distintivos del estructuralismo y de la estilística, mayoritariamente. La división arbitraria de la muestra precisamente lo que busca es la no imposición de una hipótesis absoluta, sino la comprobación de los resultados empíricos del análisis de contenido propiamente tal. Ello implica que, eventualmente, podrían aparecer caracteres discursivos de otras corrientes o tendencias teóricas, no necesariamente adscritas a las dos anteriores, procurando que la fiabilidad sea la resultante directa de los hallazgos empíricos encontrados.

Para todos los efectos del modelo metodológico utilizado, hemos prescindido de los análisis exclusivamente cuantitativos, y hemos adoptado una metodología

\footnotetext{
Para todos los efectos, hemos preferido trabajar con la muestra completa, es decir, 98 artículos de 98 números publicados de la $R C h L$, sabiendo que esta muestra podría ser potencialmente insuficiente en términos del universo total de artículos posibles de la revista; solo suponiendo que pudieran existir 5 artículos por cada número de la revista, esto nos daría como resultado una cantidad de 490 artículos totales, cifra que en la práctica debe ser mayor, pues hay números de la $R C h L$ que contienen $6,7,8$ y hasta 12 artículos o estudios por publicación, particularmente cuando se trata de números temáticos o de homenaje. De todos modos, si las cantidades fueran 98/490 estaríamos trabajando con un $20 \%$ del universo total, lo que en términos probabilísticos es una selección más que suficiente para el escrutinio del análisis de contenido (Krippendorf 191-249).
} 
cualitativa + cuantitativa, toda vez que lo que se está rastreando son unidades de análisis agrupadas bajo el concepto de rasgos distintivos de los modelos teóricos a inferir. De haber optado por una metodología de análisis cuantitativa, habría que haber considerado, entre otros procedimientos, mayoritariamente frecuencia, cuestión que para los resultados esperados podría ser irrelevante, dado que un solo concepto proveniente del estructuralismo, la estilística, o el formalismo ruso, es suficiente para la adscripción del enfoque teórico del artículo, puesto que se trata de conceptos nucleares en la dimensión del contenido al que aluden.

Ahora bien, cualquier método cuantitativo supone un registro y una adscripción codificada a las unidades catastradas, razón por la cual también hemos incorporado al procedimiento analítico unidades de registro, expresadas como un conjunto de campos estables de carácter descriptivo. De este modo, hemos establecido como unidades de registro discretas la forma textual artículo (o estudio), prescindiendo de las reseñas, documentos, notas, o cualquier otra variable de géneros textuales académicos incluidos en la $R C h L$. Así, para cada unidad de registro [artículo, estudio] hemos considerado los siguientes elementos cronológicos, numerales, contextuales, autorales, referenciales y semánticos (conceptos, procesos, objetos):

- Campo 1 - Año publicación: señala el año de la publicación; en varias ocasiones, la revista registra más de un número por año.

- Campo 2-Número(s): indica el o los números de publicación sucesivos de la $R C h L$, desde el número 1 al número 98; existen revistas que agrupan dos números en algunas ocasiones.

- Campo 3-Numeración correlativa del artículo: esta numeración es la secuencia de aparición del artículo en la revista correspondiente; por tratarse de un muestreo en etapas múltiples, hemos seleccionado los artículos mediante el esquema metodológico de configuración azarosa de la muestra; para ello, hemos iniciado la selección con los números impares $(1,3,5,7$, etc.), y una vez finalizada esta secuencia por su no aparición en el número siguiente de la $R C h L$, hemos continuado con la numeración par $(2,4,6$, etc.); una vez concluida esta sucesión, hemos regresado a la numeración impar. La alternancia de las secuencias impares/pares ha garantizado la no selección por tendencia, por afinidad temática, por reconocimiento de la autoría del artículo, etc., neutralizando con ello cualquier sesgo subjetivo ajeno al escrutinio del análisis de contenido. La codificación para 
la numeración correlativa de los artículos incluyó identificadores de año, número de la $R C h L$ y posición de aparición del artículo en el $\mathrm{N}^{\circ}$ de dicha revista; por ejemplo, [1971-04] 05: entre corchetes, primero el año de publicación, seguido del $\mathrm{N}^{\circ}$ de la revista, y fuera de los corchetes, la posición del artículo escrutado en la secuencia de artículos de la revista, expresada en la clasificación alternada impar/par.

- Campo 4-Autoría: registro del o los autores del artículo.

- Campo 5 - Título artículo: transcripción literal del título del artículo tal y como aparece expresado en la $R C h L$.

- Campo 6-Perspectiva teórica, modelo, método, conceptos, objeto: este es el campo de la unidad de registro (UR) para todos los efectos del análisis de contenido que se efectuará a continuación; sus componentes han sido organizados bajo la ordenación del esquema deductivo, es decir, jerarquizados desde lo más general a lo más particular. Estos componentes internos son:

- Perspectiva teóricalárea de estudios: refiere grosso modo la adscripción del desarrollo del artículo a alguna corriente teórica reconocible dentro de la teoría literaria contemporánea, esto es, a partir del formalismo ruso en adelante. $\mathrm{O}$ bien, se trata de un área propia de los estudios literarios: Ejemplos: estructuralismo, estilística, literatura comparada, literatura europea, literatura hispanoamericana, etc.

- Modelo: refiere la aparición explícita de algún modelo de análisis literario, asociado a alguna perspectiva teórica. Habitualmente los modelos son apropiaciones metodológicas de los contenidos epistémicos de las teorías de las cuales provienen. Ejemplo: análisis textual, análisis estructural, periodización histórica, etc.

- Método: refiere la aparición explícita de alguna metodología derivada de algún modelo o perspectiva teórica. Ejemplo: método de análisis estilístico, método de análisis métrico, método de análisis estructural del relato, etc.

- Conceptos: refiere la aparición explícita o implícita de las principales nociones provenientes del área epistemológica de origen, susceptibles de ser expresadas como conceptos genéricos o específicos. Ejemplos: relato, narrador, intertextualidad, género literario, mundo representado, etc. 
- Objeto: refiere el o los objetos de estudio o de análisis/interpretación de la perspectiva teórica, modelo, método y sus correspondientes conceptos. Ejemplo: Siglo de Oro, Rubén Darío, novela chilena contemporánea, literatura hispanoamericana del siglo XIX, modernismo, etc.

Todos estos campos se organizaron en tablas de doble entrada, donde a la categoría de las filas corresponden los campos anteriormente mencionados, y en la posición de las columnas aparecen los registros respectivos, según el orden precedente de los campos de análisis, como se puede apreciar en el siguiente ejemplo:

\begin{tabular}{|c|c|c|c|c|c|}
\hline $\begin{array}{c}\text { Año } \\
\text { publicación }\end{array}$ & $\begin{array}{c}\text { Número } \\
\text { (s) }\end{array}$ & $\begin{array}{c}\text { Numeración } \\
\text { correlativa } \\
\text { del artículo }\end{array}$ & Autoría & $\begin{array}{c}\text { Título } \\
\text { artículo }\end{array}$ & $\begin{array}{l}\text { Perspectiva teórica/ } \\
\text { área de estudios, } \\
\text { modelo, método, } \\
\text { conceptos, objeto }\end{array}$ \\
\hline 1985 & 25 & $\begin{array}{c}{[1985-25]} \\
01\end{array}$ & $\begin{array}{l}\text { Vaisman, } \\
\text { Luis }\end{array}$ & $\begin{array}{l}\text { En torno a } \\
\text { la ciencia- } \\
\text { ficción: } \\
\text { propuesta } \\
\text { para la } \\
\text { descripción } \\
\text { de un } \\
\text { género } \\
\text { histórico }\end{array}$ & $\begin{array}{l}\text { Teoría literaria, } \\
\text { teoría de los géneros, } \\
\text { géneros históricos, } \\
\text { ciencia ficción, } \\
\text { estructuralismo, teoría } \\
\text { del relato, semiótica, } \\
\text { pragmática, gramática } \\
\text { de las historias, } \\
\text { institucionalidad } \\
\text { (industria editorial, } \\
\text { consumo), estructura } \\
\text { del relato, contexto } \\
\text { de producción, } \\
\text { contexto de recepción, } \\
\text { verosimilitud, mundo } \\
\text { posible, motivos. }\end{array}$ \\
\hline
\end{tabular}

Tabla 0: Ejemplo de registro, con campos y descriptores

\section{ELOCUTIO: ANÁLISIS E INTERPRETACIÓN DEL OBJETO}

Para la redacción de este artículo, hemos efectuado el análisis de contenido inmediatamente a continuación de las tablas que dan cuenta de los cuatro tramos en los que se ha dividido el conjunto de los 98 números publicados de 
la $R C h L$. El análisis de contenido consiste en la elaboración de los comentarios que surgen de la presencia / ausencia de rasgos caracterizadores de la teoría literaria contemporánea, en cuanto filiación epistemológica y metodológica de los artículos, así como en su inscripción en los contextos históricos de producción y recepción para los estudios literarios, incluyendo la vinculación de estos con la línea editorial del Departamento de Literatura, como la entidad en la que se alojan disciplinaria y académicamente estos estudios sobre literatura al interior de la Universidad de Chile. Para ello hemos asumido que la adscripción de los conceptos del campo 6 pueden aparecer en forma explícita (presencia del rasgo) o implícita (ausencia textual o en el enunciado, del rasgo); la reconstrucción implícita de estos rasgos, supone, de suyo, un conocimiento mínimo de la historia de la teoría literaria contemporánea, en sus principales autores, escuelas y textos.

\section{III.1. PRIMER TRAMO: Nº 1 AL 25 (1970-1985)}

\begin{tabular}{|c|c|c|c|c|c|}
\hline $\begin{array}{c}\text { Año } \\
\text { publicación }\end{array}$ & $\begin{array}{l}\text { Número } \\
\text { (s) }\end{array}$ & $\begin{array}{l}\text { Numeración } \\
\text { correlativa } \\
\text { del artículo }\end{array}$ & Autoría & Título artículo & $\begin{array}{l}\text { Perspectiva teórica/ } \\
\text { área de estudios, } \\
\text { modelo, método, } \\
\text { conceptos, objeto }\end{array}$ \\
\hline & 01 & $\begin{array}{c}{[1970-01]} \\
01\end{array}$ & $\begin{array}{c}\text { Goic, } \\
\text { Cedomil }\end{array}$ & $\begin{array}{c}\text { Poética del } \\
\text { exordio en "La } \\
\text { Araucana" }\end{array}$ & $\begin{array}{l}\text { Poética, retórica, } \\
\text { estilística, literatura } \\
\text { comparada, literatura } \\
\text { europea, literatura } \\
\text { medieval y del } \\
\text { renacimiento, literatura } \\
\text { española, género lírico, } \\
\text { épica, Siglo de Oro, } \\
\text { Alonso de Ercilla, La } \\
\text { Araucana. }\end{array}$ \\
\hline 1970 & $02-03$ & $\begin{array}{c}\text { [1970-02- } \\
03] 03\end{array}$ & $\begin{array}{l}\text { Rojo, } \\
\text { Grínor }\end{array}$ & $\begin{array}{c}\text { Estado } \\
\text { actual de las } \\
\text { investigaciones } \\
\text { sobre teatro } \\
\text { hispanoamericano } \\
\text { contemporáneo }\end{array}$ & $\begin{array}{c}\text { Literatura } \\
\text { comparada, literatura } \\
\text { hispanoamericana, } \\
\text { historia de la literatura } \\
\text { hispanoamericana, } \\
\text { teatro } \\
\text { hispanoamericano } \\
\text { contemporáneo, } \\
\text { historia moderna } \\
\text { del teatro } \\
\text { hispanoamericano } \\
\text { contemporáneo, }\end{array}$ \\
\hline
\end{tabular}




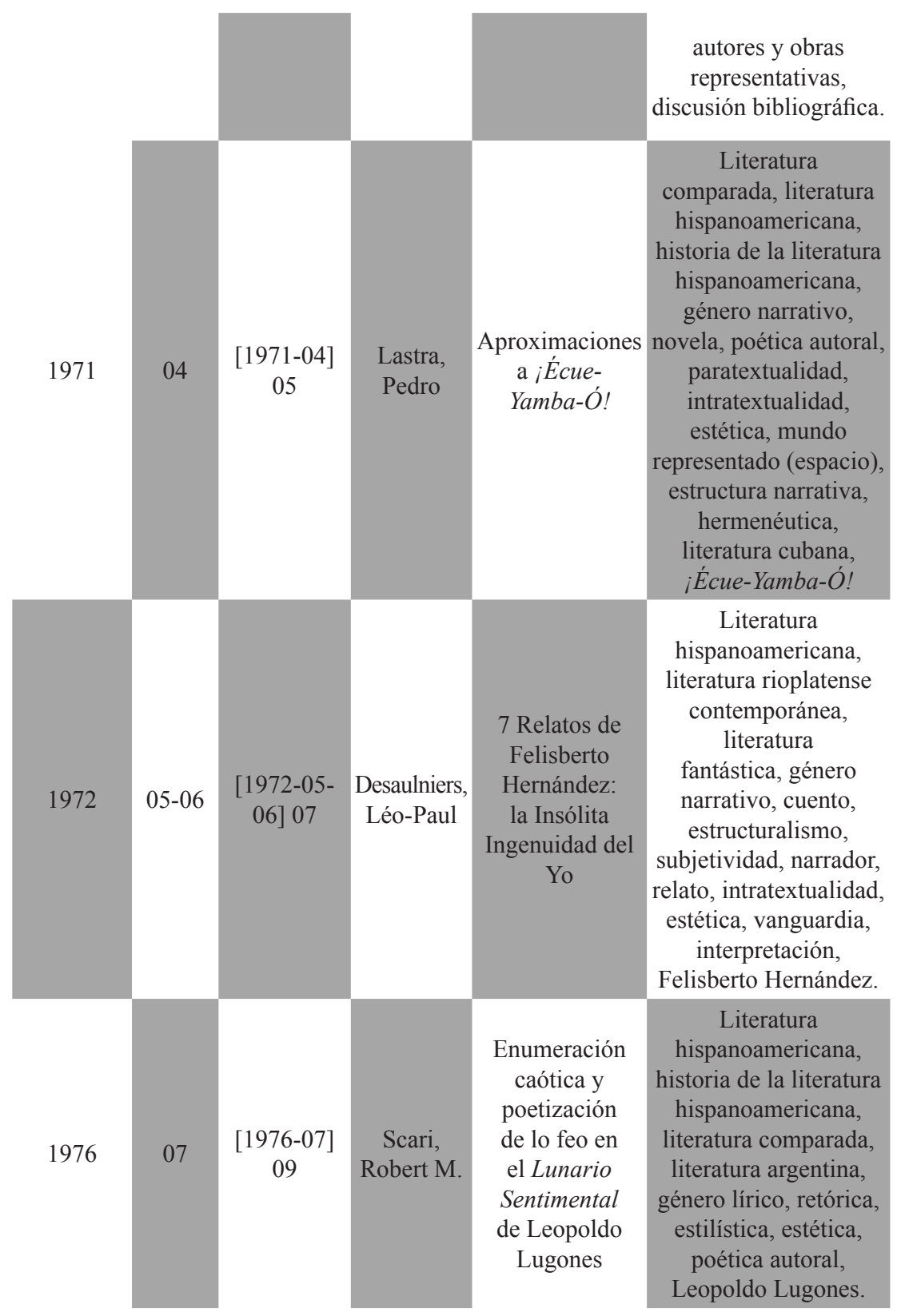




\begin{tabular}{|c|c|c|c|c|c|}
\hline \multirow{2}{*}{1977} & 08 & $\begin{array}{c}{[1977-08]} \\
02\end{array}$ & $\begin{array}{c}\text { Montes, } \\
\text { Hugo }\end{array}$ & $\begin{array}{c}\text { Las oraciones } \\
\text { del Cid }\end{array}$ & $\begin{array}{l}\text { Literatura europea, } \\
\text { literatura española, } \\
\text { historia de la literatura } \\
\text { española, literatura } \\
\text { medieval, género } \\
\text { narrativo, género } \\
\text { lírico, épica, estilística, } \\
\text { hermenéutica } \\
\text { (cristiana), El Mío Cid } \\
\text { Campeador. }\end{array}$ \\
\hline & $09-10$ & $\begin{array}{c}\text { [1977-09- } \\
10] 04\end{array}$ & $\begin{array}{l}\text { García, } \\
\text { Eladio }\end{array}$ & $\begin{array}{l}\text { Oda a Francisco } \\
\text { Salinas: Una } \\
\text { apertura } \\
\text { metodológica }\end{array}$ & $\begin{array}{l}\text { Literatura europea, } \\
\text { literatura española, } \\
\text { Siglo de Oro, género } \\
\text { lírico, oda, mística, } \\
\text { ascética, estilística, } \\
\text { retórica, simbología, } \\
\text { hermenéutica, } \\
\text { intratextualidad, Fray } \\
\text { Luis de León, Oda a } \\
\text { Francisco Salinas. }\end{array}$ \\
\hline \multirow[t]{2}{*}{1978} & 11 & $\begin{array}{c}{[1978-11]} \\
01\end{array}$ & $\begin{array}{c}\text { Montes, } \\
\text { Hugo }\end{array}$ & $\begin{array}{l}\text { Canciones de } \\
\text { Caminantes } \\
\text { en la poesía de } \\
\text { Eichendorff }\end{array}$ & $\begin{array}{l}\text { Literatura europea, } \\
\text { literatura alemana, } \\
\text { romanticismo, } \\
\text { literatura comparada, } \\
\text { historiografía, género } \\
\text { lírico, canción, } \\
\text { estilística, poética } \\
\text { autoral, tópica } \\
\text { (viaje), motivos, } \\
\text { figuras de dicción, } \\
\text { intratextualidad, } \\
\text { traducción. }\end{array}$ \\
\hline & 12 & $\begin{array}{c}{[1978-12]} \\
03\end{array}$ & $\begin{array}{l}\text { Suárez, } \\
\text { Ramón }\end{array}$ & $\begin{array}{l}\text { Dos textos de } \\
\text { Michel Butor }\end{array}$ & $\begin{array}{l}\text { Literatura europea, } \\
\text { literatura francesa } \\
\text { contemporánea, } \\
\text { literatura comparada, } \\
\text { género narrativo, } \\
\text { novela, semiótica, } \\
\text { análisis descriptivo, } \\
\text { interpretación, tópica } \\
\text { (viaje), motivos, } \\
\text { intratextualidad, } \\
\text { poética autoral, figuras }\end{array}$ \\
\hline
\end{tabular}




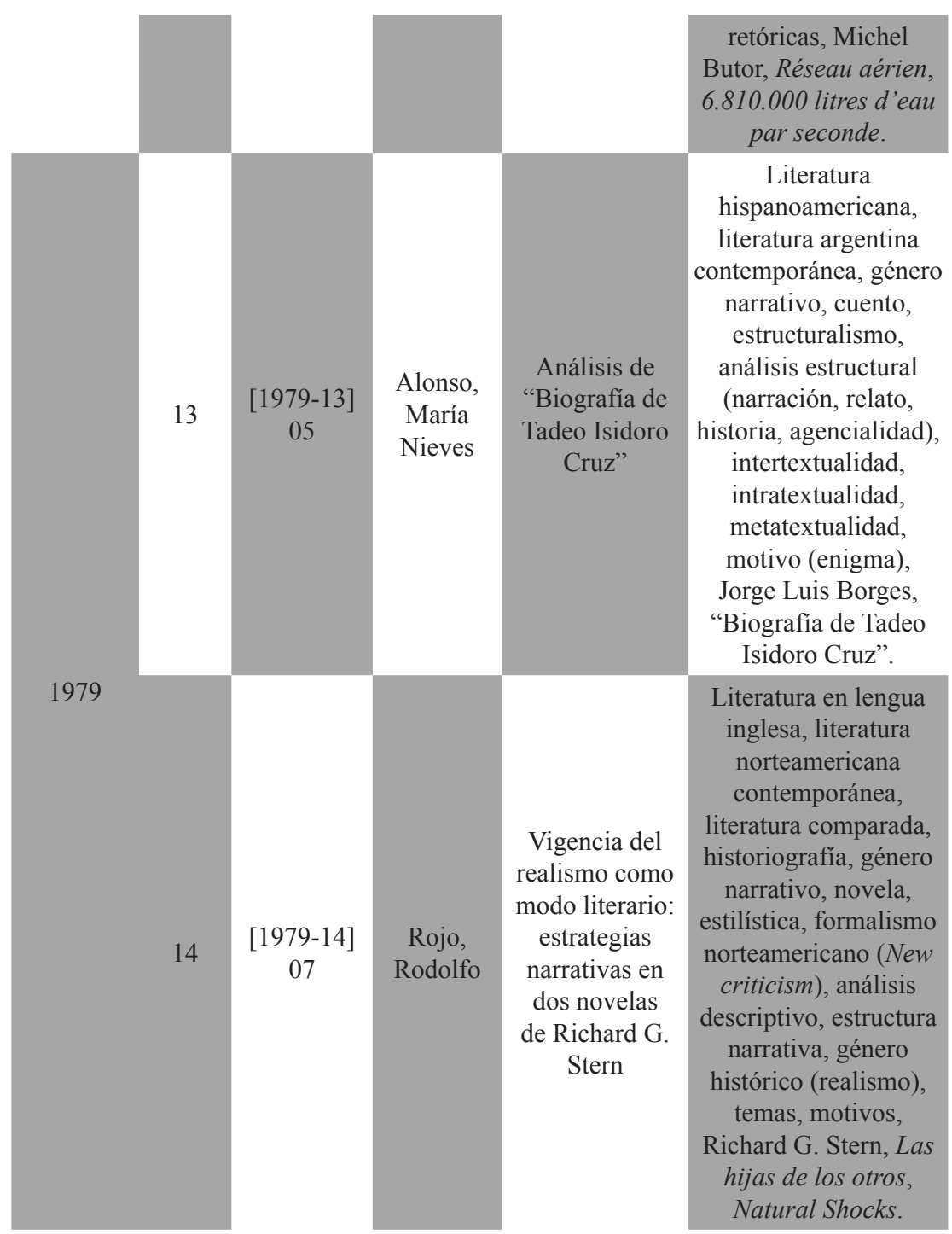




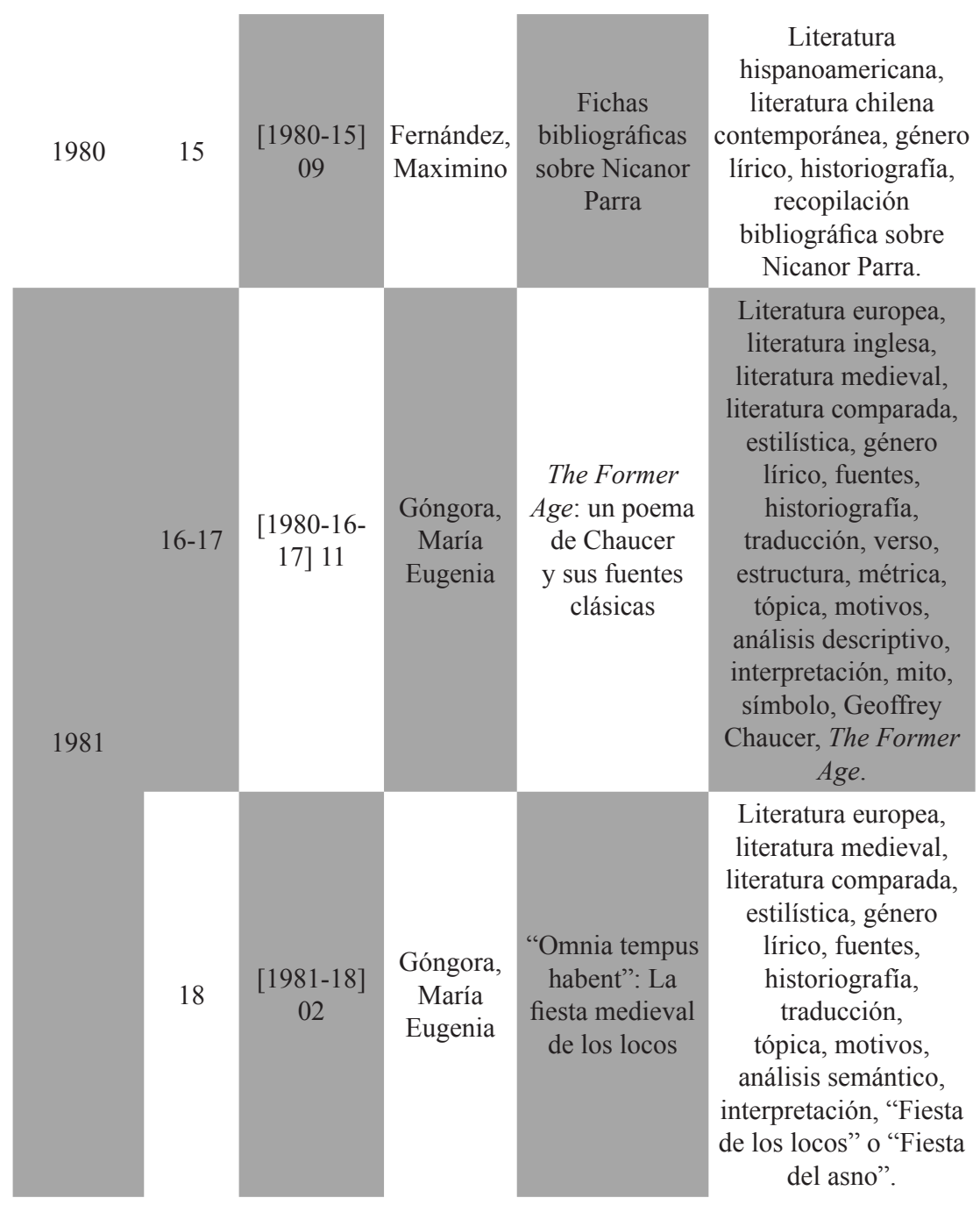




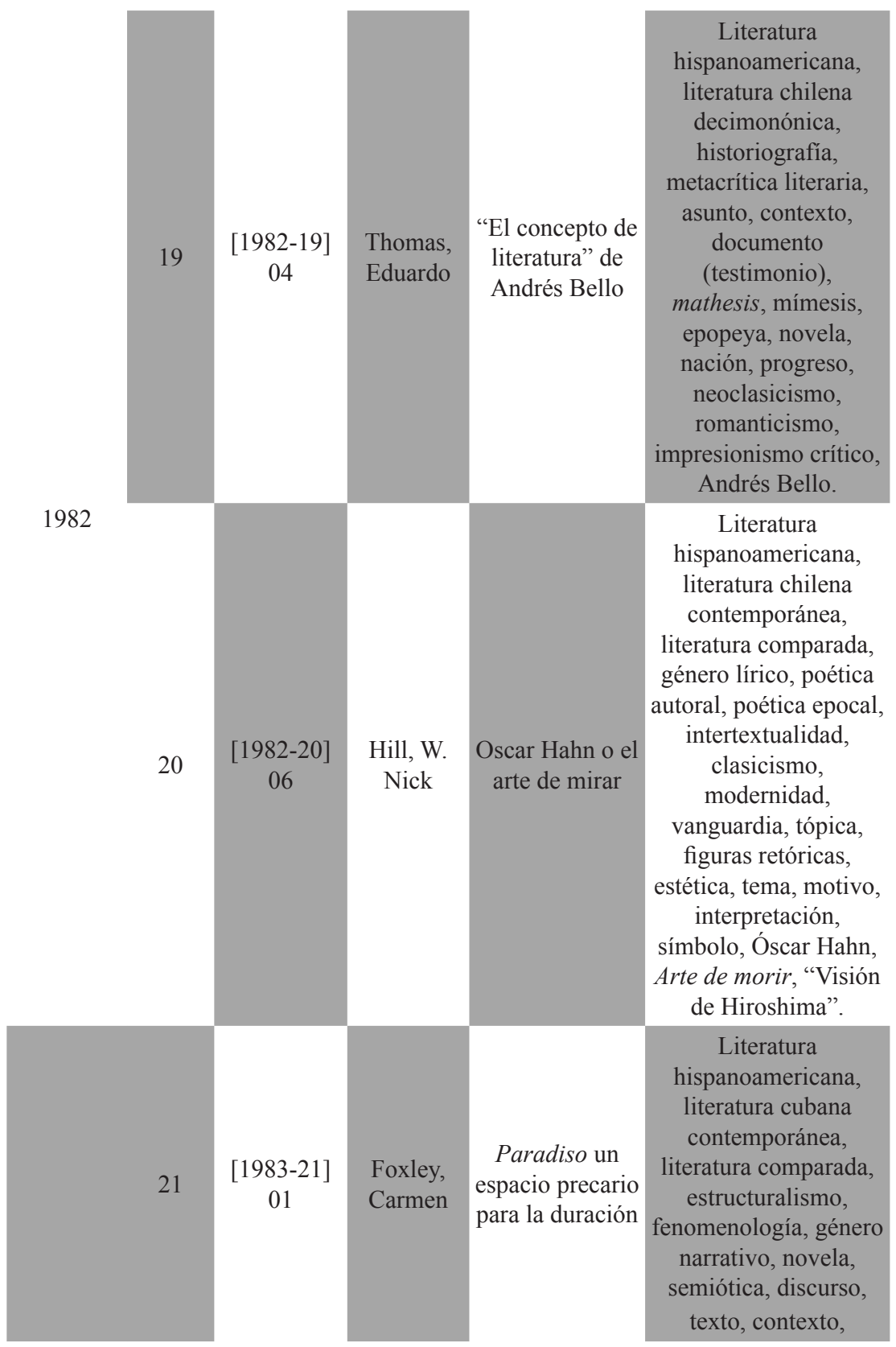




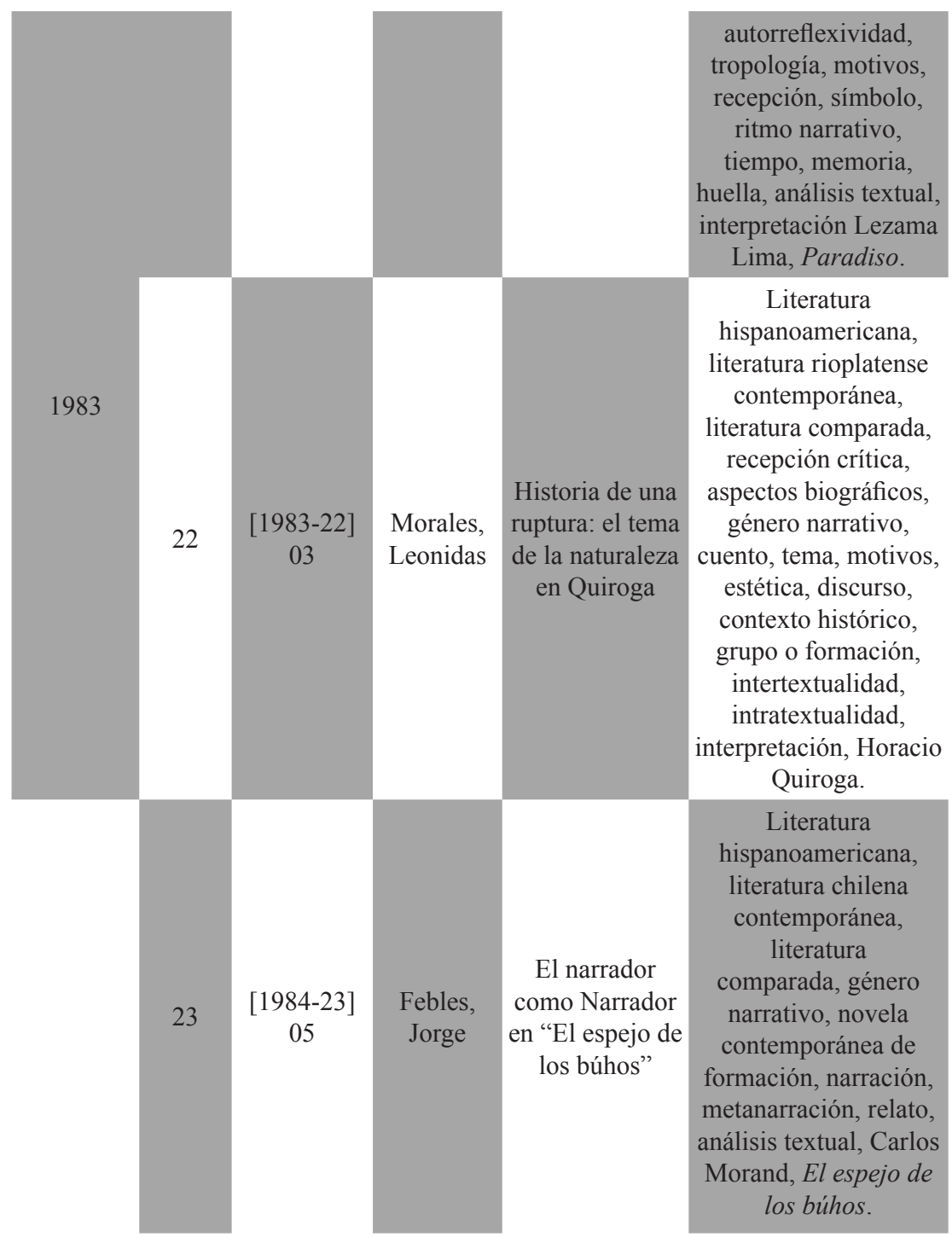


1984

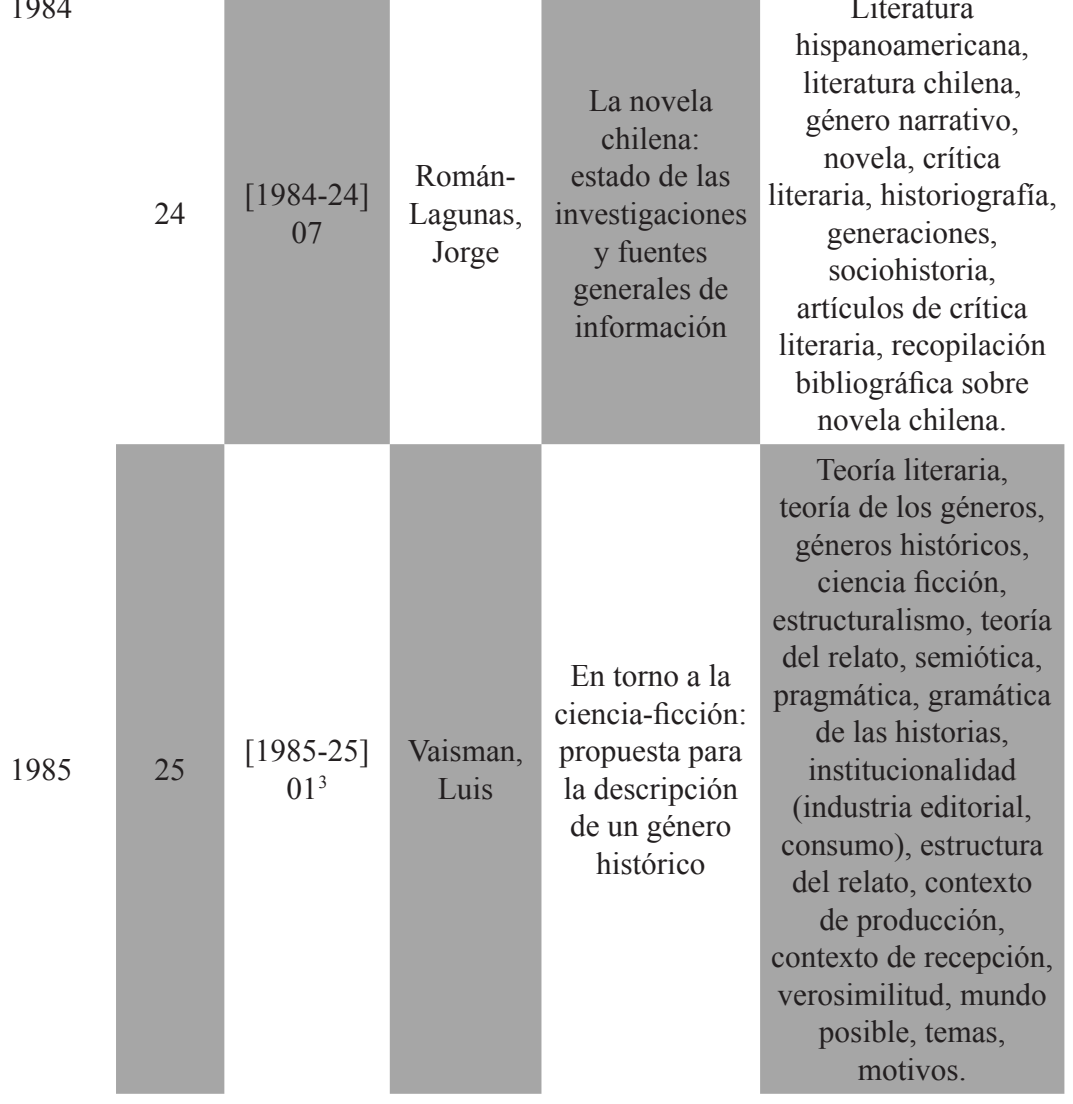

Tabla 1: unidades de registro 1970-1985; fuente: elaboración propia ${ }^{3}$

3 Si bien, de acuerdo con el método explicitado en los fundamentos teóricos de la metodología de este trabajo, correspondería revisar el artículo que ocupa el segundo lugar dentro de este número de la $R C h L$, este se trata de una conferencia leída en el Acto Inaugural del Tercer Seminario Nacional de Estudios Literarios, realizado en la Universidad de La Frontera, Temuco, Chile, el 20 de noviembre de 1984. Por ello, hemos decidido marginar este texto, pues no corresponde a la categoría de artículo o estudio, y hemos incluido el primer artículo del número 25 . A contar del número 26, retomaremos la secuencia de la numeración par, a fin de mantener el criterio de selección azarosa dirigida de la muestra. 
Desde el punto de vista de una historia de la teoría literaria del siglo XX, en 1970 nos encontramos con la fase final del estructuralismo en su período de vigencia europeo, y la aparición de lo que se conocería posteriormente como postestructuralismo o en otras denominaciones, desconstrucción (Asensi 2003, Culler 1992, Estébanez, Fokkema e Ibsch, etc.). Si bien postestructuralismo y deconstrucción no son necesariamente sinónimos, ni abarcan los mismos campos epistemológicos, modelos ni métodos, desde un punto de vista diacrónico ocupan un segmento temporal casi en forma paralela, que terminaría por sustituir completamente al estructuralismo (Culler 1992). Lo interesante de esta transformación sería que el propio estructuralismo instalara algunas de las líneas, variables y objetos de análisis que darían cabida a estas dos corrientes de estudios literarios, por lo cual no pueden ni deben ser entendidos como movimientos opuestos o contradictorios, sino como fases sucesivas y complementarias de la historia de la teoría literaria de la segunda mitad del siglo XX (Asensi 2003: 253-436; Culler 1978).

Para todos los efectos del análisis de contenido, la descripción anterior haría suponer la presencia de estas corrientes de investigación literaria en los descriptores del Campo 6 - Perspectiva teóricalárea de estudios, modelo, método, conceptos, objeto, del presente artículo, a nivel de los supuestos teóricos que están implicados en la redacción de los textos escrutados, dada la contigüidad cronológica de los mismos con las escuelas de teoría literaria del período. Sin embargo, la evidencia hallada revela una situación distinta, sobre todo, al considerar el desfase temporal entre la formulación de estas líneas teóricas en territorio europeo, y su difusión y utilización en América Latina (Moreno y Carvajal). Si bien en los primeros 25 números de la $R C h L$ encontramos una marcada presencia de literatura europea, preferentemente española, los principales marcadores conceptuales de este tramo están referidos fundamentalmente a literatura comparada, estilística, literatura hispanoamericana (Franco). La presencia de estructuralismo es muy baja (4 ocurrencias), y se trata más bien de perspectivas globales sobre estructura de los textos literarios o de su discurso, antes que de la aplicación de una metodología cuya raigambre esté indiscutiblemente asociada a esta corriente de estudios. El primero de estos estudios hallados corresponde al investigador canadiense Léo-Paul Desaulniers (UR [1972-05-06] 07), quien cita, además, a algunos de los principales autores estructuralistas en su lengua nativa (francés), en virtud de su filiación a la Universidad de Montreal. El segundo artículo de esta misma tendencia teórica corresponde a María Nieves Alonso (UR [1979-13] 05), el tercero, a Carmen Foxley (UR [1983-21] 01), y el 
cuarto, a Luis Vaisman (UR [1985-25] 01), de nacionalidad chilena estos tres últimos, la segunda perteneciente a la Universidad de Concepción, y los dos posteriores a la Universidad de Chile, precisamente al Departamento de Literatura y al área de Teoría Literaria del mismo.

La tendencia teórica dominante de este primer tramo, sin embargo, son los estudios provenientes de la literatura hispanoamericana (15 ocurrencias), la literatura comparada (13 ocurrencias), la estilística ( 8 ocurrencias) y la historiografia (7 ocurrencias). La prevalencia de la literatura hispanoamericana obedece a dos causales predeterminadas contextualmente: la primera, como área de estudios distintiva de la época y de los enfoques de filiación europea y española, y la segunda, como una derivación de los estudios de literatura comparada. La presencia decisiva de esta última corriente de estudios parece permear la casi totalidad de este primer tramo, toda vez que incluso la literatura hispanoamericana era concebida en similares condiciones de análisis que la literatura comparada. Esta última es una heredera indiscutida de la comparatística, y con una declarada filiación germánica; esta disciplina pretende subsumir varias áreas de estudios: conecta jerárquicamente con la filología, postula la posibilidad de una ciencia literaria (o ciencia de la literatura), establece una plataforma de estudios diacrónicos y contextuales, mediante una historia de la literatura, y formula las bases para la existencia de una crítica literaria (Estébanez 196-200, Gnisci, Guillén, Viñas). Tal como puede apreciarse, se trata de una macro-disciplina, cuyos vórtices se extienden más allá del campo literario, incrustándose en el corazón mismo de las humanidades y de las ciencias sociales e, incluso, bordeando otros campos disciplinarios conexos, tales como el derecho, la psicología, la historia, etc. (SELGYC). Su principio constructivo descansa en la premisa metodológica de la suposición en la isomorfía del fenómeno cultural denominado literatura, cuyas formas de estudios pretenderán reconocer transversalmente dichas manifestaciones en objetos literarios de diversas épocas, sociedades y estadios culturales, asimilándolos a una matriz de comparación (principio de semejanza / diferencia [específica]), que debería hacer visibles los rasgos distintivos de este fenómeno único, a pesar de las diferencias parciales que pudieran encontrarse (Gnisci, Guillén).

Es interesante advertir que, precisamente, en este contexto teórico, disciplinario y de fijación de áreas de estudio, aparezca la literatura chilena con 13 ocurrencias para este primer tramo de la publicación de la $R C h L$, disputando el campo de estudios, tanto a literatura hispanoamericana (donde habitualmente estaba subsumida, en caso de aparición como objeto de 
análisis), y claramente en oposición a la dominancia abstracta de la literatura comparada; puesto que, a esta última, en cambio, podríamos considerarla en tanto campo o área de estudios cuya especificidad discursiva es constitutiva de nuestro país como nación, discernible en sus manifestaciones culturales, literarias, en términos de un constructo teórico y pragmático, con objetos de estudio propios, distintivos y poseedores de los rasgos caracterizadores de una literatura nacional (Franco). No en vano, Chile ostenta dos Premios Nobel de Literatura (sintomáticamente, en poesía, además), teniendo en cuenta la escasa población de este país, su aislamiento geográfico y muchas veces cultural, y estableciendo como punto de comparación inmediato a la Argentina, considerada la quinta potencia económica mundial a comienzos del siglo $\mathrm{XX}^{4} \mathrm{y}$ que, a pesar de su ingente y excelente producción literaria, no cuenta con dos distinciones análogas de rango planetario, como los Premios Nobel de Literatura de Gabriela Mistral (1945) y Pablo Neruda (1971).

Similar irrupción discursiva, textual y temática se verá en el T3 ( $\mathrm{N}^{\circ} 51$ al 75, entre 1997 y 2009), cuando emerjan definitivamente en la selección de publicación de artículos para la $R C h L$ en su línea editorial las perspectivas de los estudios desconstructivos, poscoloniales, culturales, de perspectiva de género, psicocrítica, etc., exhibiendo un cambio en el paradigma de los estudios literarios. La aparición sistemática de literatura chilena (Fernández; Foresti, Löfquist, Foresti; Goic 1972, 1997; Muñoz y Oelker; Promis 1977, 1993, 1995; Rojo, Arcos y Massmann; Subercaseaux) en este primer tramo $\left(\mathrm{N}^{\circ} 1\right.$ al 25 , entre 1970 y 1985) es equiparable en términos de un orden del discurso perimido que es sustituido por otro, emergente, y que desplaza al anterior, en la conocida disputa por el dominio del campo discursivo (Maingueneau 19) y su correspondiente formación (Maingueneau 37-39; 51-52). Sin ingresar en el detalle del posible análisis ideológico respectivo, solo baste indicar que en el T1 nos encontramos con la desaparición de la legalidad constitucional

4 Cfr. https://www.libremercado.com/2012-04-22/argentina-de-pais-rico-a-paispobre-1276456223/ (consultado el 22-03-2019). Si bien no suscribimos la corriente ideológica de la fuente de esta información, sí nos parece relevante en términos de la documentación que implica, toda vez que describe detalladamente, con un metalenguaje económico, períodos históricos coherentes con los hechos de la historia, en términos generales, y propone argumentativamente una explicación acerca del tránsito de la riqueza a la pobreza en Argentina sin considerar otras variables epistemológicas y metodológicas que sean ajenas al capitalismo, al liberalismo y al neoliberalismo, esto es, representando una concepción conservadora, posiblemente retrógrada y arcaizante, de la historia económica y su conexión con la historia social, cultural, discursiva y textual de la historia argentina contemporánea. 
representada por el golpe de estado de 1973 en Chile, y el subsecuente estado de anulación, cancelación y suspensión de derechos fundamentales, tanto en lo civil como en lo penal y jurídico en general, circunstancia que está histórica y contextualmente incluida en la línea editorial de la $R C h L$ en términos de la selección temática de los artículos para este tramo. Sin embargo, es notorio también el modo en que comienza a configurarse un discurso contrahegemónico en virtud de la implantación metodológica de un objeto de estudio preexistente (la literatura chilena), que ya no es entendida como un área de subducción jerárquicamente dependiente de otra mayor o más aplastante, sino como una demarcación propia, con una clara pretensión de configuración epistemológica ad hoc, a fin de constituirse en un objeto de estudio teórico-crítico susceptible de desestabilizar los discursos de la crítica hegemónica surgida al amparo de la dictadura, en la institucionalización forzada y forzosa de los discursos sobre cultura, educación, enseñanza de la literatura, etc. Pero solo recién en el T2 ( N²6 al 50, entre 1985 y 1997) se podrá apreciar en régimen este cambio discursivo anunciado en el T1.

III.2. Segundo tRAmO: Nº 26 AL 50 (1985-1997)

\begin{tabular}{|c|c|c|c|c|c|}
\hline $\begin{array}{c}\text { Año } \\
\text { publicación }\end{array}$ & $\begin{array}{l}\text { Número } \\
\text { (s) }\end{array}$ & $\begin{array}{l}\text { Numeración } \\
\text { correlativa } \\
\text { del artículo }\end{array}$ & Autoría & Título artículo & $\begin{array}{l}\text { Perspectiva teórica/área de } \\
\text { estudios, modelo, método, } \\
\text { conceptos, objeto }\end{array}$ \\
\hline 1985 & 26 & [1985-26] 04 & $\begin{array}{l}\text { Hozven, } \\
\text { Roberto }\end{array}$ & $\begin{array}{l}\text { El discurso } \\
\text { del ensayo, a } \\
\text { propósito de } \\
\text { O côntrôle do } \\
\text { imaginário }\end{array}$ & $\begin{array}{l}\text { Literatura latinoamericana, } \\
\text { literatura brasileña, } \\
\text { literatura comparada, } \\
\text { ensayo, historiografía, } \\
\text { lecturas, mímesis, } \\
\text { sociología, estructuralismo, } \\
\text { semiótica, estética } \\
\text { de la recepción, } \\
\text { postestructuralismo, } \\
\text { psicoanálisis, } \\
\text { intersubjetividad, } \\
\text { contexto de recepción, } \\
\text { ideología, reescritura, } \\
\text { intertextualidad, análisis } \\
\text { textual, Luiz Costa Lima, } \\
\text { O controle do imaginário: } \\
\text { Razilo eimaginário no } \\
\text { Occidente }\end{array}$ \\
\hline
\end{tabular}




\begin{tabular}{|c|c|c|c|c|c|}
\hline 1986 & $27-28$ & $\begin{array}{c}{[1986-27-28]} \\
06\end{array}$ & $\begin{array}{c}\text { Scheerer, } \\
\text { Thomas M. }\end{array}$ & $\begin{array}{c}\text { Tiempos } \\
\text { infelices, sobre } \\
\text { la novela } \\
\text { histórica de } \\
\text { Mariano José de } \\
\text { Larra }\end{array}$ & $\begin{array}{c}\text { Literatura europea, } \\
\text { literatura española, } \\
\text { historiografía, género } \\
\text { narrativo, novela histórica, } \\
\text { biografía, época, leyenda, } \\
\text { intertextualidad, tema, } \\
\text { motivos, interpretación, } \\
\text { Mariano José de Larra, El } \\
\text { doncel de don Enrique el } \\
\text { Doliente }\end{array}$ \\
\hline \multirow[t]{2}{*}{1987} & 29 & [1987-29] 08 & $\begin{array}{l}\text { Gotschlich, } \\
\text { Guillermo }\end{array}$ & $\begin{array}{c}\text { Grotesco y } \\
\text { tragicomedia } \\
\text { en El ideal de } \\
\text { un calavera de } \\
\text { Alberto Blest } \\
\text { Gana }\end{array}$ & $\begin{array}{c}\text { Literatura } \\
\text { hispanoamericana, } \\
\text { literatura chilena, literatura } \\
\text { comparada, género } \\
\text { narrativo, realismo, novela, } \\
\text { novela costumbrista, } \\
\text { tema, motivos, estética, } \\
\text { grotesco, tragicomedia, } \\
\text { paratextualidad, poética } \\
\text { autoral, Alberto Blest Gana, } \\
\text { El ideal de un calavera. }\end{array}$ \\
\hline & 30 & [1987-30] 01 & $\begin{array}{l}\text { Grassi, } \\
\text { Ernesto }\end{array}$ & $\begin{array}{c}\text { El problema } \\
\text { filosófico del } \\
\text { tiempo en Proust }\end{array}$ & $\begin{array}{l}\text { Literatura europea, } \\
\text { literatura francesa, } \\
\text { género narrativo, novela, } \\
\text { filosofía, metafísica, } \\
\text { lógica, fenomenología, } \\
\text { hermenéutica, estética, } \\
\text { tema, motivos, tiempo, } \\
\text { memoria, metaliteratura, } \\
\text { Marcel Proust, En busca } \\
\text { del tiempo perdido. }\end{array}$ \\
\hline 1988 & 31 & [1988-31] 03 & Durán, Juan & $\begin{array}{l}\text { Secuencias } \\
\text { paralelas en } \\
\text { "La compuerta } \\
\mathrm{N}^{\circ} 12 \text { ", de } \\
\text { Baldomero Lillo }\end{array}$ & $\begin{array}{c}\text { Literatura } \\
\text { hispanoamericana, } \\
\text { literatura chilena, género } \\
\text { narrativo, cuento, poética } \\
\text { autoral, sociología, } \\
\text { intertextualidad, } \\
\text { naturalismo, tema, } \\
\text { motivos, análisis textual, } \\
\text { interpretación, Baldomero } \\
\text { Lillo, "La compuerta } \\
\text { número 12". }\end{array}$ \\
\hline
\end{tabular}




\begin{tabular}{|c|c|c|c|c|c|}
\hline & 32 & [1988-32] 05 & $\begin{array}{l}\text { Cortínez, } \\
\text { Verónica }\end{array}$ & $\begin{array}{l}\text { Polifonía: } \\
\text { Entrevista a } \\
\text { Isabel Allende } \\
\text { y Antonio } \\
\text { Skármeta }\end{array}$ & $\begin{array}{c}\text { Entrevista sobre } \\
\text { literatura latinoamericana } \\
\text { (paratexto), literatura } \\
\text { chilena, género narrativo, } \\
\text { novela, cuento, autores, } \\
\text { identidad, historia, cultura, } \\
\text { literatura fundacional, } \\
\text { literatura del boom } \\
\text { latinoamericano, literatura } \\
\text { post-boom, poética autoral, } \\
\text { contexto político (golpe de } \\
\text { estado y dictadura), Isabel } \\
\text { Allende, Antonio Skármeta. }\end{array}$ \\
\hline \multirow[t]{3}{*}{1989} & 33 & [1989-33] 07 & $\begin{array}{c}\text { Gotschlich, } \\
\text { Guillermo }\end{array}$ & $\begin{array}{c}\text { Ceremonia } \\
\text { Secreta } \text { de } \\
\text { Marco Denevi; } \\
\text { enigma y } \\
\text { ritualización }\end{array}$ & $\begin{array}{l}\text { Literatura latinoamericana, } \\
\text { literatura argentina, } \\
\text { literatura comparada, } \\
\text { género narrativo, novela } \\
\text { contemporánea, tema, } \\
\text { motivos, narrador - lector, } \\
\text { focalización, enigma, } \\
\text { mito, rito, discurso, } \\
\text { símbolo, interpretación, } \\
\text { Marco Denevi, Ceremonia } \\
\text { Secreta. }\end{array}$ \\
\hline & 34 & [1989-34] 02 & $\begin{array}{c}\text { Montes, } \\
\text { Hugo }\end{array}$ & $\begin{array}{c}\text { Poemas inéditos } \\
\text { y dispersos } \\
\text { de Vicente } \\
\text { Huidobro }\end{array}$ & $\begin{array}{c}\text { Literatura } \\
\text { hispanoamericana, } \\
\text { literatura chilena, } \\
\text { vanguardias, género lírico, } \\
\text { publicaciones, ediciones, } \\
\text { compilaciones, paratexto, } \\
\text { temas, motivos, estilística, } \\
\text { interpretación, Vicente } \\
\text { Huidobro, Poemas inéditos } \\
\text { y dispersos. }\end{array}$ \\
\hline & 35 & [1990-35] 04 & $\begin{array}{l}\text { Cánovas, } \\
\text { Rodrigo }\end{array}$ & $\begin{array}{l}\text { Úrsula Suárez } \\
\text { (monja chilena, } \\
\text { 1666-1749): la } \\
\text { autobiografía } \\
\text { como penitencia }\end{array}$ & $\begin{array}{c}\text { Literatura } \\
\text { hispanoamericana, } \\
\text { literatura chilena, literatura } \\
\text { colonial, historiografía, } \\
\text { filología, retórica de } \\
\text { la cultura, géneros } \\
\text { referenciales, relación, } \\
\text { autobiografía, testimonio, } \\
\text { documento, oralidad, } \\
\text { identidad, tema, motivos, } \\
\text { interpretación, Úrsula } \\
\text { Suárez. }\end{array}$ \\
\hline
\end{tabular}




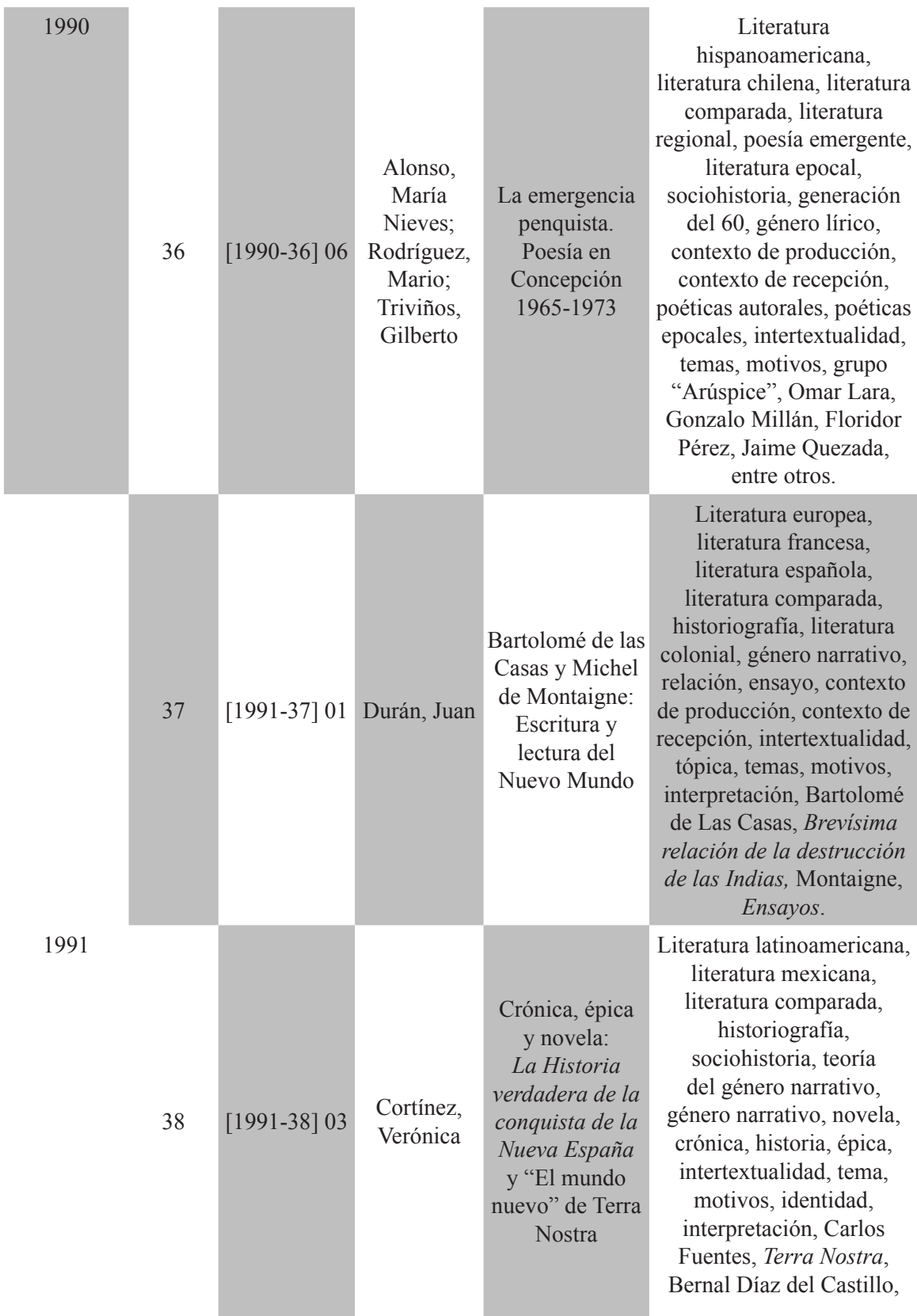




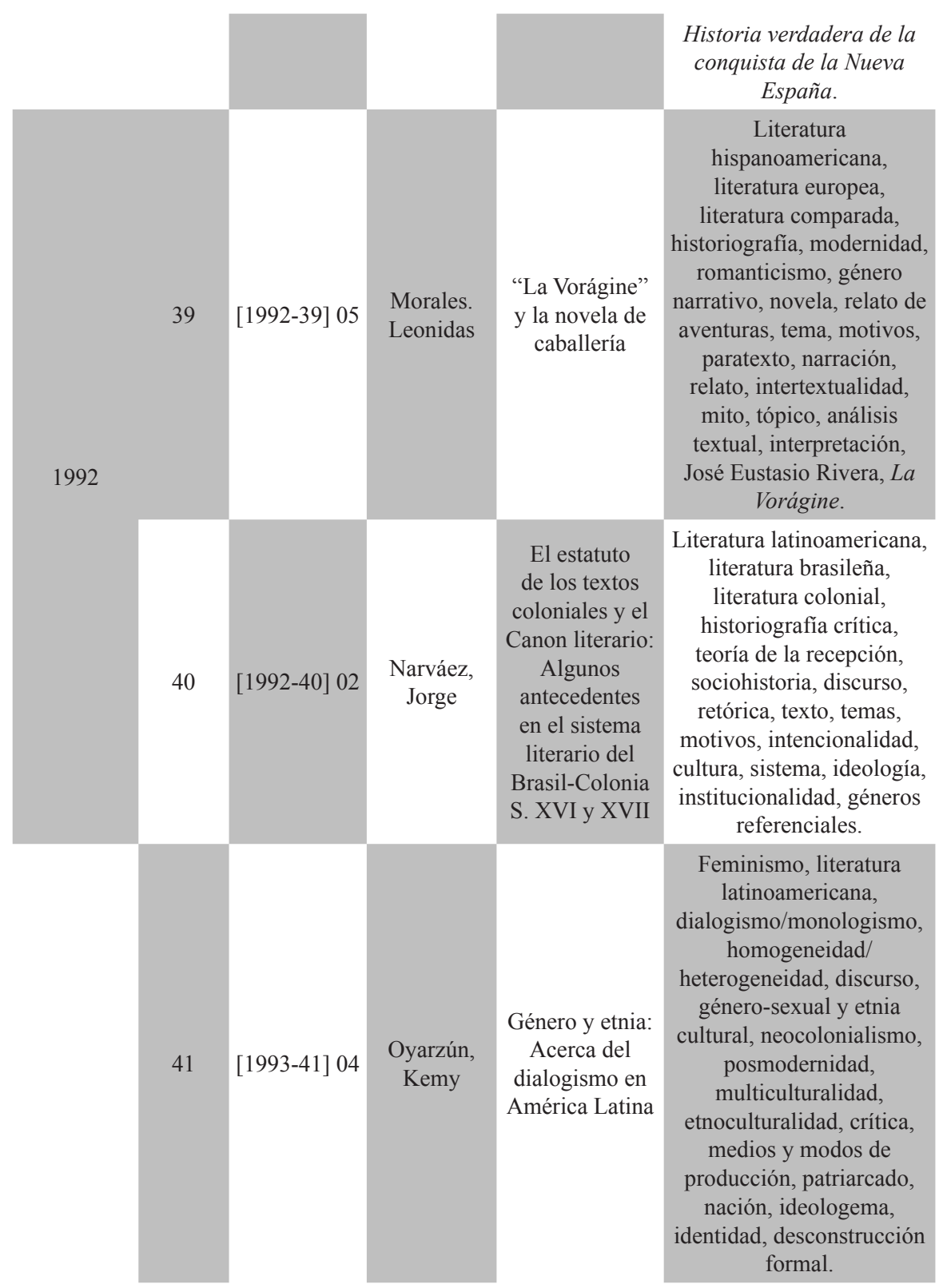




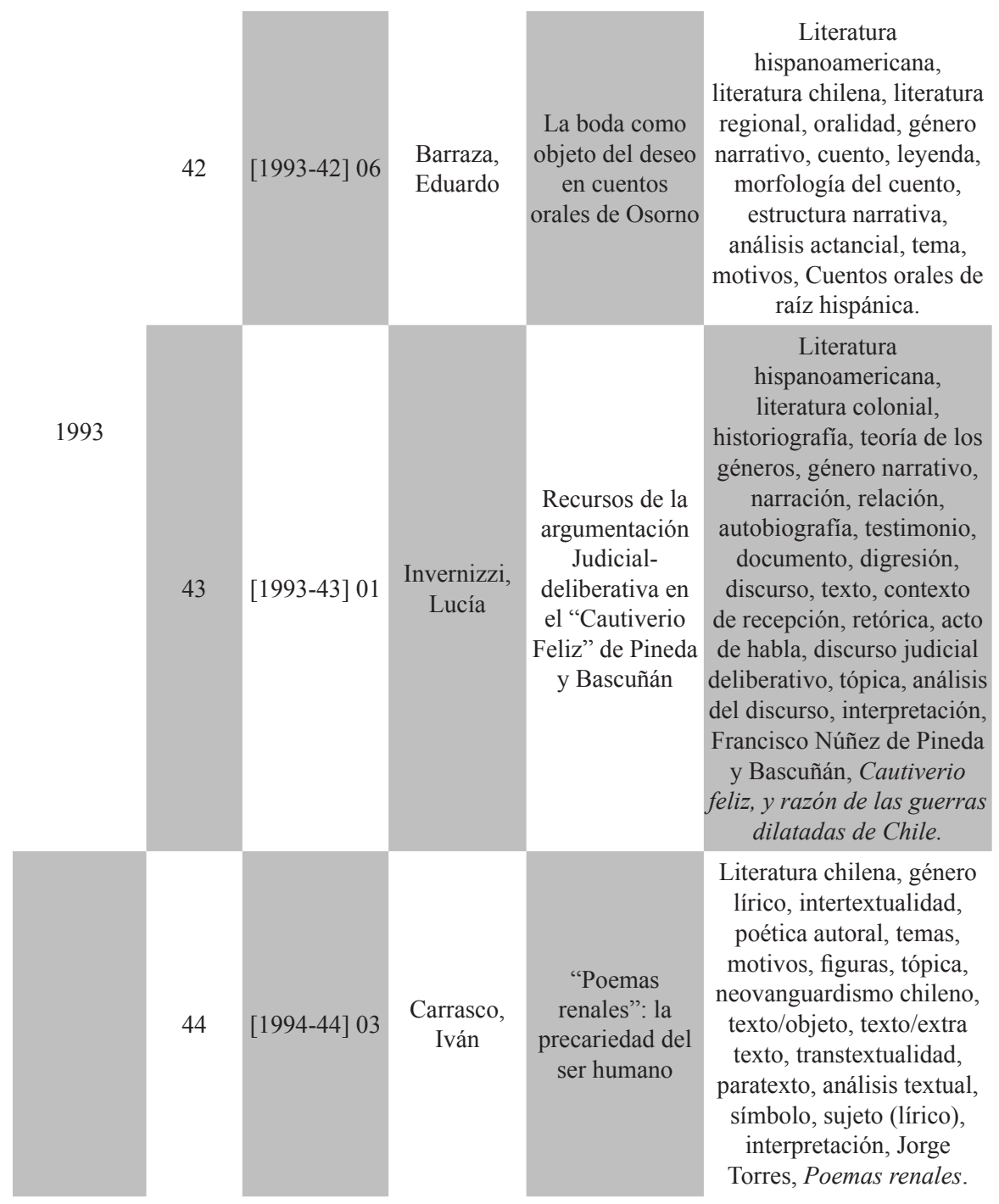




\begin{tabular}{|c|c|c|c|c|c|}
\hline 1994 & 45 & [1994-45] 05 & $\begin{array}{l}\text { Morales, } \\
\text { Leonidas }\end{array}$ & $\begin{array}{l}\text { El "Diario" de } \\
\text { Luis Oyarzún }\end{array}$ & $\begin{array}{l}\text { Literatura latinoamericana, } \\
\text { literatura chilena, género } \\
\text { narrativo, géneros de } \\
\text { la intimidad, literatura } \\
\text { comparada, autobiografía, } \\
\text { diario de vida, } \\
\text { historiografía, modernidad, } \\
\text { intertextualidad, estética, } \\
\text { discurso, temas, motivos, } \\
\text { figuras, Luis Oyarzún, } \\
\text { Diario intimo. }\end{array}$ \\
\hline \multirow{3}{*}{1995} & 46 & [1995-46] 02 & $\begin{array}{l}\text { Godoy, } \\
\text { Eduardo }\end{array}$ & $\begin{array}{l}\text { "El rey y la } \\
\text { reina", de } \\
\text { Ramón Sender y } \\
\text { el encuentro con } \\
\text { "el otro" }\end{array}$ & $\begin{array}{l}\text { Literatura europea, } \\
\text { literatura española, género } \\
\text { narrativo, temas, motivos, } \\
\text { relato, análisis textual, } \\
\text { interpretación, Ramón } \\
\text { Sender, El Rey y la Reina }\end{array}$ \\
\hline & 47 & [1995-47] 04 & $\begin{array}{l}\text { Cobián, } \\
\text { Dora Luz }\end{array}$ & $\begin{array}{l}\text { El papel de la } \\
\text { mujer en la } \\
\text { historia maya- } \\
\text { quiché, según el } \\
\text { "Popol Vuh" }\end{array}$ & $\begin{array}{c}\text { Literatura } \\
\text { precolombina, literatura } \\
\text { hispanoamericana, } \\
\text { literatura colonial, } \\
\text { historiografía, género } \\
\text { narrativo, polifonía, } \\
\text { perspectiva de género } \\
\text { (feminismo), paradigma } \\
\text { patriarcal, deconstrucción, } \\
\text { configuración mitológica, } \\
\text { sociohistoria, análisis } \\
\text { textual, roles de personajes } \\
\text { femeninos, contexto de } \\
\text { producción, contexto de } \\
\text { recepción, interpretación, } \\
\text { Popol Vuh. }\end{array}$ \\
\hline & 48 & [1996-48] 01 & $\begin{array}{c}\text { Videla de } \\
\text { Rivero, } \\
\text { Gloria }\end{array}$ & $\begin{array}{l}\text { La poesía como } \\
\text { celebración vital } \\
\text { en dos textos de } \\
\text { Jorge Guillén } \\
\text { y de Jorge } \\
\text { Ramponi }\end{array}$ & $\begin{array}{l}\text { Literatura europea, } \\
\text { literatura española, } \\
\text { literatura latinoamericana, } \\
\text { literatura argentina, } \\
\text { literatura comparada, } \\
\text { género lírico, } \\
\text { intertextualidad, imagen, } \\
\text { símbolo, análisis } \\
\text { textual, tema, motivos, } \\
\text { interpretación, Jorge } \\
\text { Guillén, "Gallo del } \\
\text { amanecer"; Jorge Ramponi, } \\
\text { "Imágenes para un ave del } \\
\text { alba". }\end{array}$ \\
\hline
\end{tabular}




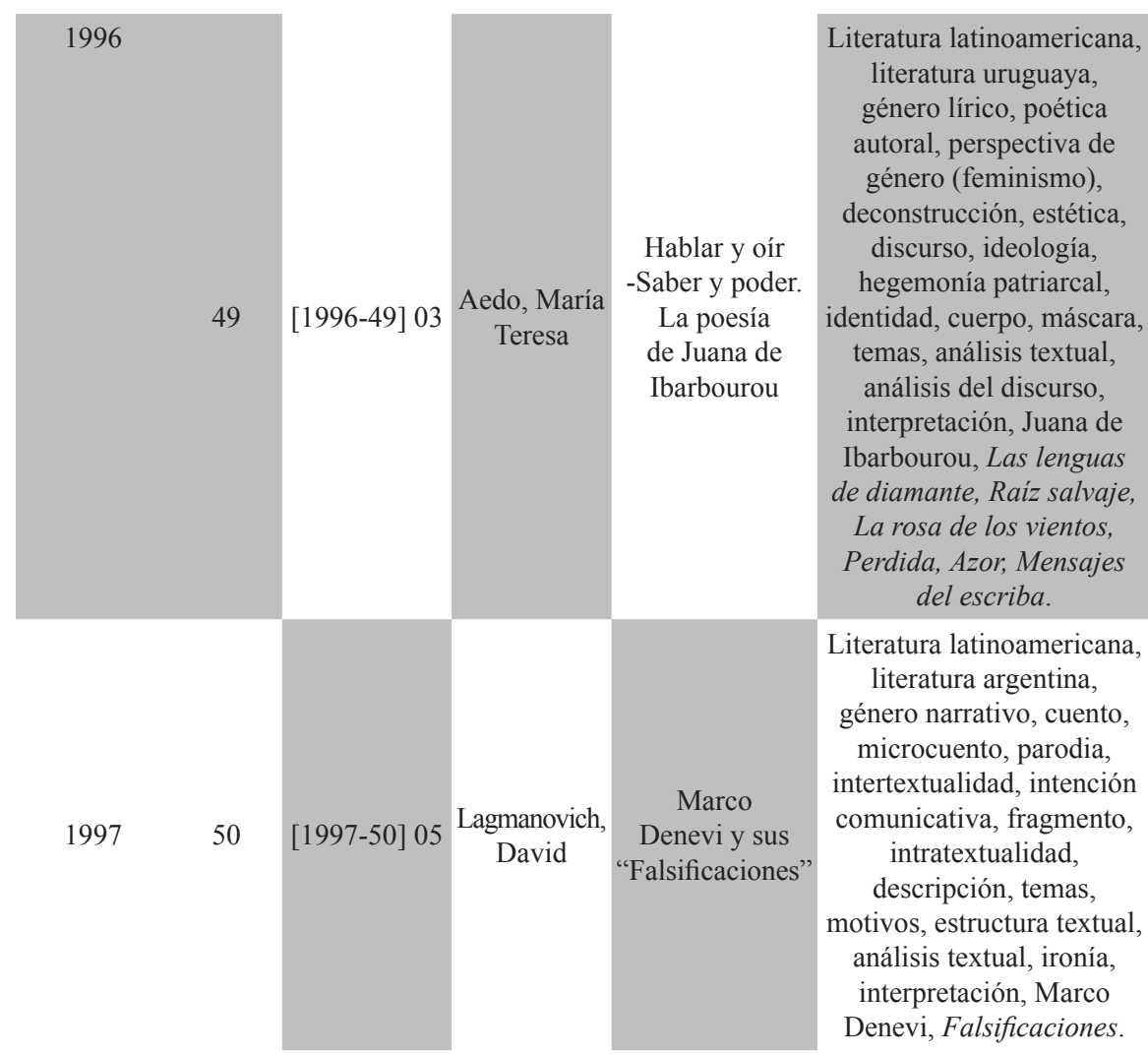

Tabla 2: unidades de registro 1985-1997; fuente: elaboración propia

Ya en el segundo tramo advertimos la inclusión del concepto de literatura latinoamericana que representa un significativo avance, pues aborda regionalmente los objetos de estudio. Siete artículos generan relaciones con otras literaturas dentro de este contexto. Por ello, la perspectiva comparatística sigue presente, aunque ahora centrada en el diálogo que se establece entre la literatura escrita en portugués y también del resto de América Latina.

La recuperación de conceptos tradicionales, como el de mímesis, se amplía a un sistema de representación que catapulta los análisis estructurales a los planos sociológicos e ideológicos (sobre todo en lo que dice relación con el concepto de subjetividad) y postestructurales que ponen énfasis en los marcos $\mathrm{u}$ horizontes de expectativas (Jauss) donde emerge epocalmente el lector y 
la lectura. A la vez, el modelo psicocrítico, incluye tanto el pensamiento tradicional de Freud como la relectura de este por Lacan, para la construcción dialógica de la subjetividad que, al mismo tiempo, se funda en los aportes de Kristeva a partir de la incorporación dentro de Occidente del pensamiento crítico de Bajtin referido al discurso, dialogismo e intertextualidad. En última instancia, el análisis ya no solo reconoce la autonomía del texto literario, sino que lo expande a una serie de intervenciones sociales en tanto elementos constitutivos de él.

No obstante, las perspectivas tradicionales conviven con estos cambios, en la medida en que subsiste la teoría de la interpretación tradicional, es decir, la que identifica núcleos semánticos para ser intencionados dentro de una tradición hegemónica, como la española, en pos del establecimiento de una verdad (Gadamer, pero antes Eliot y Pound, por ejemplo) con respecto a géneros históricos, como la autobiografía y leyenda, y la ubicación del objeto literario desde un punto de vista intertextual e historiográfico. Aunque el tercer artículo analizado en este tramo (UR [1987-29] 08) no representa variaciones significativas con respecto al anterior, con relación a los géneros históricos, sí exhibe ciertas características provenientes de categorías estéticas (grotesco), autorales (poéticas) y genéricas (tragicomedia) para "leer" El ideal de un calavera de Blest Gana. Sin embargo, hay otros trabajos que, aunque recuperan elementos provenientes de la tradición con respecto a la novela, incorporan conceptos de análisis filosófico (fenomenología y el desarrollo del concepto de intención) para solventar una interpretación del imaginario o, en propiedad, el de imaginación.

La reflexión sobre la dimensión paratextual, esto es, la entrevista en este caso (UR[1988-32] 05), busca obtener, a través de las respuestas de los autores, un fundamento para la inclusión de ellos dentro del desarrollo de la literatura chilena en el exilio, así como su lugar en la producción contradictatorial. Solo un aspecto relevante aparece en el siguiente artículo (UR [1989-33] 07) y es el relativo al concepto de focalización, ya que evidencia desde una perspectiva teórica lo enunciado por Mieke Bal en su proposición narratológíca de la focalización (FE/FI/F0); el resto de los artículos, emplea los mismos conceptos habituales referidos a tradiciones, períodos, géneros, etc.

También hay espacio para la publicación de (re)copilaciones, por ejemplo, la de poemas de Vicente Huidobro, que realzan el papel del editor por sobre las características de los poemas (UR [1989-34] 02). Sin embargo, la difusión de literatura chilena reciente, la del grupo Arúspice, considera regionalmente (con Concepción como la ciudad sede de la VIII Región) la literatura y su 
pertenencia a una determinada generación (1960), incluyendo elementos nominales, poéticos, sociohistóricos, contextuales, etc. (UR [1990-36] 06).

A pesar de la perspectiva tradicional que se utiliza para analizar los textos de Úrsula Suárez, pensamos que la incorporación de nociones como referencialidad, esto es, discurso, en la medida en que este se vincula al testimonio y al documento, se textualiza genéricamente en la relación como género histórico (UR [1990-35] 04). Aspecto que también se proyecta en el análisis historiográfico de la obra de Bartolomé de las Casas (UR [199137] 01), si bien se incluyen reflexiones sobre los contextos de producción y recepción mediante un vínculo entre sus escritos y los de Montaigne: los ensayos. Asimismo, las obras de Bernal Díaz del Castillo son tratadas desde un punto de vista genérico, pero también son abordadas desde el problema de la identidad a partir de aquel hasta Carlos Fuentes (UR [1991-38] 03). Elementos que también aborda Lucía Invernizzi (UR [1993-43] 01), pero lo hace desde un corpus teórico que no solo incorpora categorías propias del análisis del discurso (Lozano, Peña-Marín, Abril), sino también aspectos provenientes de los géneros retóricos (judicial, deliberativo y epidíctico) y las partes de este (inventio, dispositivo, elocutio, etc.). Así, y desde esta perspectiva, la autora revisa tópicos, actos de habla performativos (Austin y Searle) y los interpreta poniendo en duda ciertas apropiaciones por parte de la institucionalidad crítica nacional con respecto al texto.

El trabajo sobre los campos ideológicos, es decir, sobre la noción de hegemonía e institucionalidad, se fundamenta en la interpretación que realizan Narváez (UR [1992-40] 02) y Oyarzún (UR [1993-41] 04). Esta última, sin embargo, opone el monologismo de un sistema patriarcal con el dialogismo, la homogeneidad y heterogeneidad, el género-sexual, las etnias, entre otros, desmantelando o descontruyendo el binarismo que porta la ideología. En la misma línea, Dora Cobián (UR [1995-47] 04) utiliza el mismo aparataje teórico, que se centra en el paradigma feminista dentro del análisis de género, para referirse a los roles de los personajes femeninos en el Popol Vuh. María Teresa Aedo (UR [1996-49] 03) se inscribe y escribe dentro de esta tendencia que expone cómo la crítica feminista, mediante la desconstrucción, ha ido instalándose en las nuevas lecturas de los problemas de género e identidad. Dentro de los mismos números de la $R C h L$ analizados y descritos, no solo en las tablas, sino también en los comentarios, sigue existiendo una perspectiva tradicional, la de Eduardo Godoy (UR [1995-46] 02), que recorre los temas y motivos desde una óptica textualista, es decir, a través del análisis del relato y la interpretación. Gloria Videla (UR [1996-48] 01) trabaja la noción 
de intertextualidad y no reconoce las diferencias entre símbolos, alegorías, imágenes y metáforas; por lo cual se puede concluir que la pervivencia de la estilística sigue predominando en gran parte del modelo crítico hispánico. Más adelante, Lagmanovich (UR [1997-50] 05) también incorpora la noción de intertexto, vinculándolo con la parodia e ironía.

Eduardo Barraza (UR [1993-42] 06) regresa a una perspectiva anterior al estructuralismo, es decir, al formalismo, recuperando aspectos propios de la estructura narratológica descrita por Propp y que es, luego, analizada desde el modelo actancial (Greimas). En Poemas renales, Iván Carrasco (UR [1994-44] 03) utiliza un aparato conceptual que depende, en sentido amplio, de la noción de transtextualidad, pero que considera también las dimensiones simbólicas desde un punto de vista interpretativo.

Por último, Leonidas Morales (UR [1994-45] 05) trabaja los distintos géneros de la intimidad (autobiografía, diarios de vida) presentes en la obra de Luis Oyarzún, desde dimensiones historiográficas modernas, mediante conceptos como intertextualidad, estética, análisis del discurso, etc. Conviene advertir que la introducción de la referencialidad se debe en gran parte a él dentro de la escena crítica chilena.

III.3. TERCER TRAMO: Nº 51 AL 75 (1997-2009)

\begin{tabular}{|c|c|c|c|c|c|}
\hline $\begin{array}{c}\text { Año } \\
\text { publicación }\end{array}$ & $\begin{array}{c}\text { Número } \\
\text { (s) }\end{array}$ & $\begin{array}{l}\text { Numeración } \\
\text { correlativa } \\
\text { del artículo }\end{array}$ & Autoría & Título artículo & $\begin{array}{l}\text { Perspectiva teórica/área } \\
\text { de estudios, modelo, } \\
\text { método, conceptos, objeto }\end{array}$ \\
\hline 1997 & 51 & [1997-51] 02 & $\begin{array}{c}\text { Fabry, } \\
\text { Geneviève }\end{array}$ & $\begin{array}{l}\text { Las aporías de } \\
\text { la visión en la } \\
\text { novelística de } \\
\text { Manuel Puig }\end{array}$ & $\begin{array}{c}\text { Literatura } \\
\text { latinoamericana, literatura } \\
\text { argentina, género } \\
\text { narrativo, novela, } \\
\text { focalización, imagen, } \\
\text { cuerpo, significación, } \\
\text { parodia, cliché, } \\
\text { pseudorrealismo, } \\
\text { indeterminación, } \\
\text { teoría de la recepción, } \\
\text { paradoja, análisis textual, } \\
\text { interpretación, Manuel } \\
\text { Puig, Boquitas pintadas, } \\
\text { El beso de la mujer } \\
\text { araña, Pubis angelical, } \\
\text { Cae la noche tropical. }\end{array}$ \\
\hline
\end{tabular}




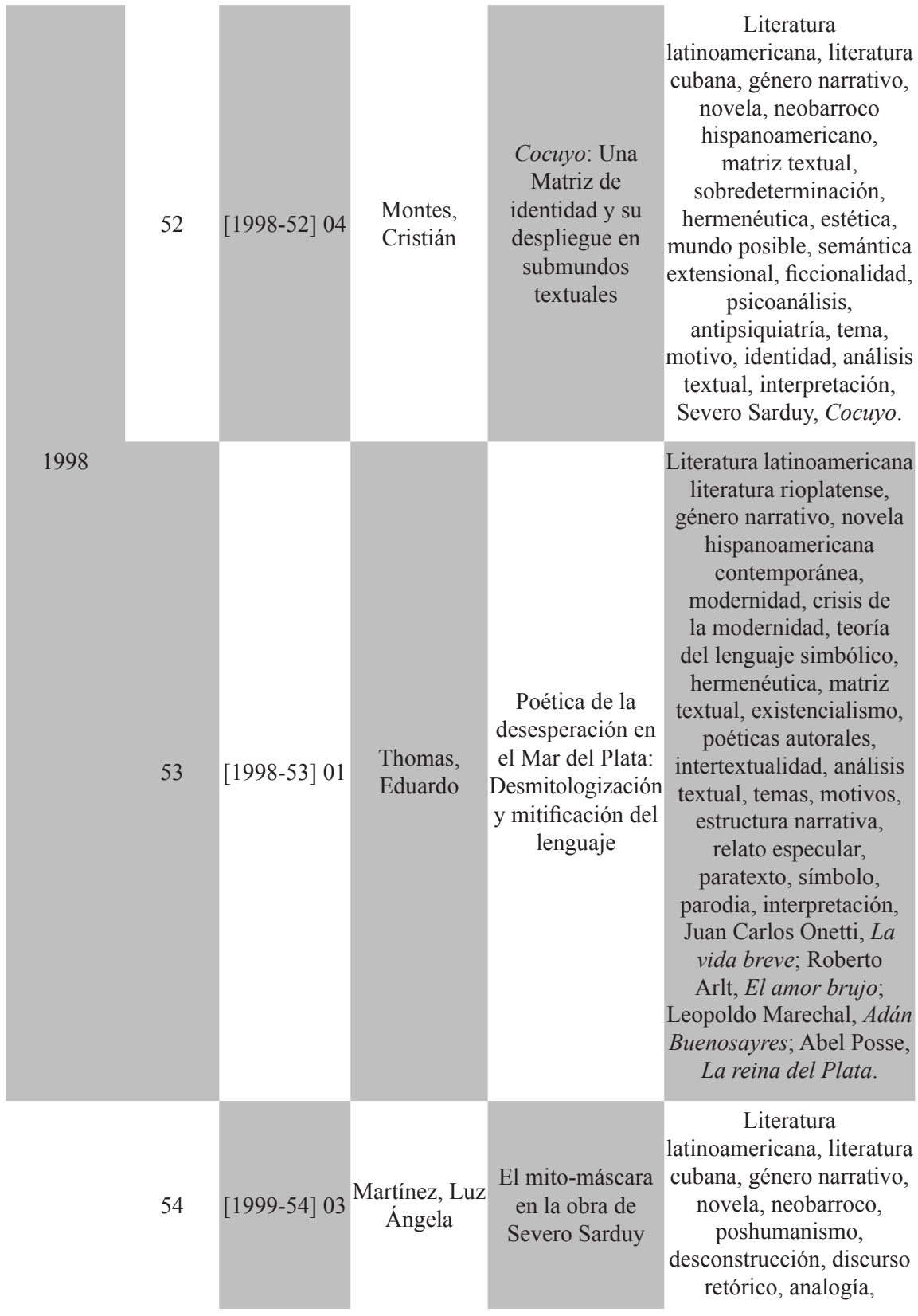




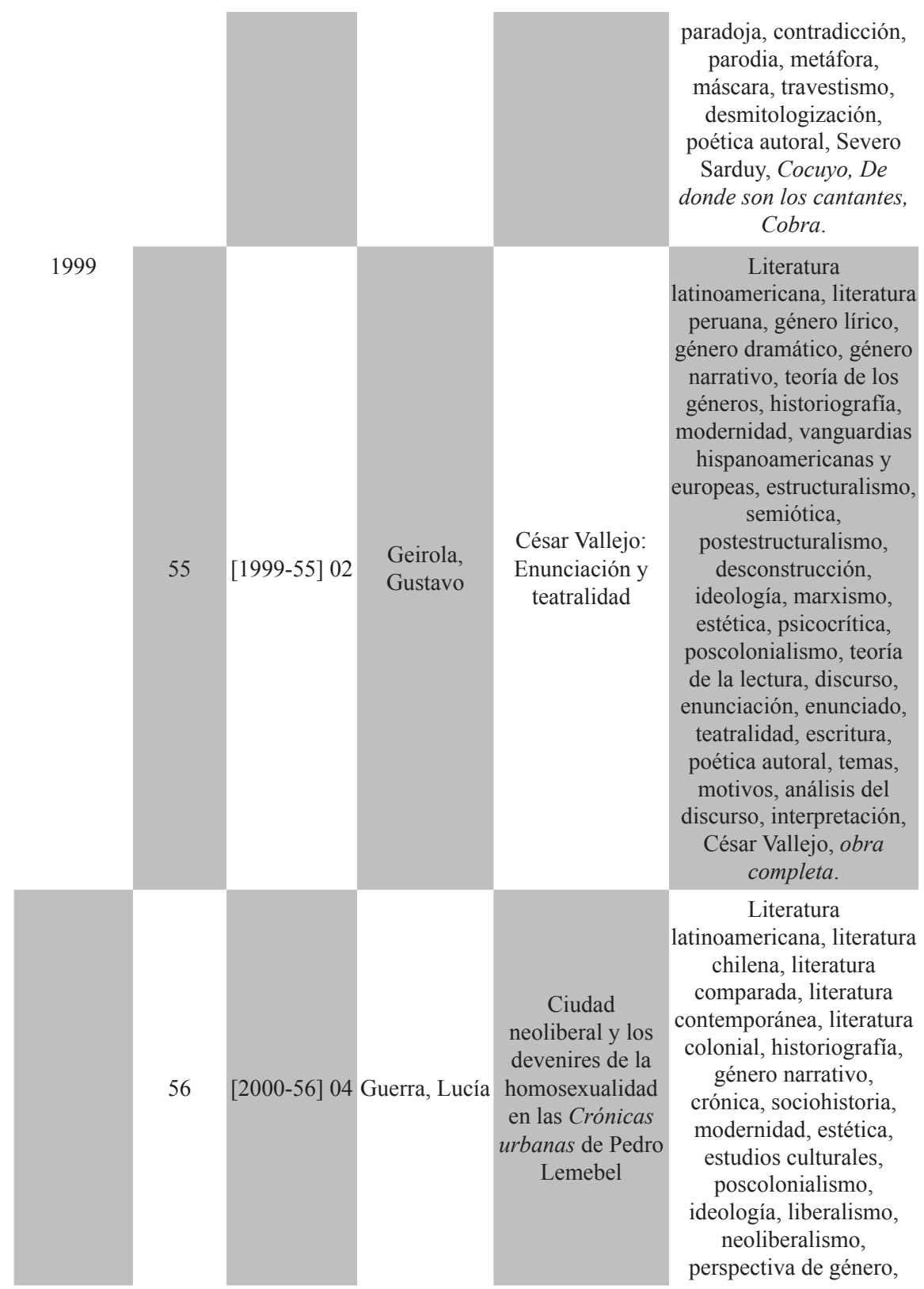




\begin{tabular}{|c|c|c|c|c|c|}
\hline \multirow[b]{2}{*}{2000} & & & & & $\begin{array}{c}\text { homosexualidad, } \\
\text { psicocrítica, análisis del } \\
\text { discurso, intertextualidad, } \\
\text { paratextualidad, cuerpo, } \\
\text { carnaval, ciudad, Pedro } \\
\text { Lemebel, Crónicas } \\
\text { urbanas. }\end{array}$ \\
\hline & 57 & [2000-57] 01 & $\begin{array}{l}\text { Góngora, } \\
\text { María } \\
\text { Eugenia }\end{array}$ & $\begin{array}{c}\text { La obra literaria } \\
\text { de Hildegard de } \\
\text { Bingen (1098 - } \\
1179)\end{array}$ & $\begin{array}{c}\text { Literatura europea, } \\
\text { literatura medieval, } \\
\text { literatura alemana, } \\
\text { literatura mística, } \\
\text { historiografía, género } \\
\text { lírico, canción, filología, } \\
\text { sujeto de la enunciación, } \\
\text { intratextualidad, análisis } \\
\text { textual, temas, motivos, } \\
\text { interpretación, traducción, } \\
\text { Hildegard de Bingen, } \\
\text { Symphonia armoniae } \\
\text { celestium revelationum. }\end{array}$ \\
\hline \multirow[b]{2}{*}{2001} & 58 & [2001-58] 03 & Plaza, Dino & $\begin{array}{c}\text { "Vaca Sagrada": } \\
\text { la propuesta de } \\
\text { Diamela Eltit }\end{array}$ & $\begin{array}{c}\text { Literatura } \\
\text { latinoamericana, literatura } \\
\text { chilena, literatura } \\
\text { contemporánea, género } \\
\text { narrativo, novela, } \\
\text { estructura narrativa, } \\
\text { tiempo, postmodernidad, } \\
\text { desconstrucción, } \\
\text { escritura, perspectiva } \\
\text { de género, ideología, } \\
\text { discurso, cuerpo, temas, } \\
\text { motivos, análisis textual, } \\
\text { análisis del discurso, } \\
\text { interpretación, Diamela } \\
\text { Eltit, Vaca sagrada. }\end{array}$ \\
\hline & 59 & [2001-59] 02 & $\begin{array}{c}\text { Pellegrini, } \\
\text { Marcelo }\end{array}$ & $\begin{array}{c}\text { Poesía en /de } \\
\text { transición: Raúl } \\
\text { Zurita y "La vida } \\
\text { nueva" }\end{array}$ & $\begin{array}{l}\text { Literatura } \\
\text { hispanoamericana, } \\
\text { literatura chilena, } \\
\text { literatura contemporánea, } \\
\text { género lírico, } \\
\text { historiografía, metacrítica, } \\
\text { neovanguardismo chileno, } \\
\text { contexto de producción y } \\
\text { recepción, }\end{array}$ \\
\hline
\end{tabular}




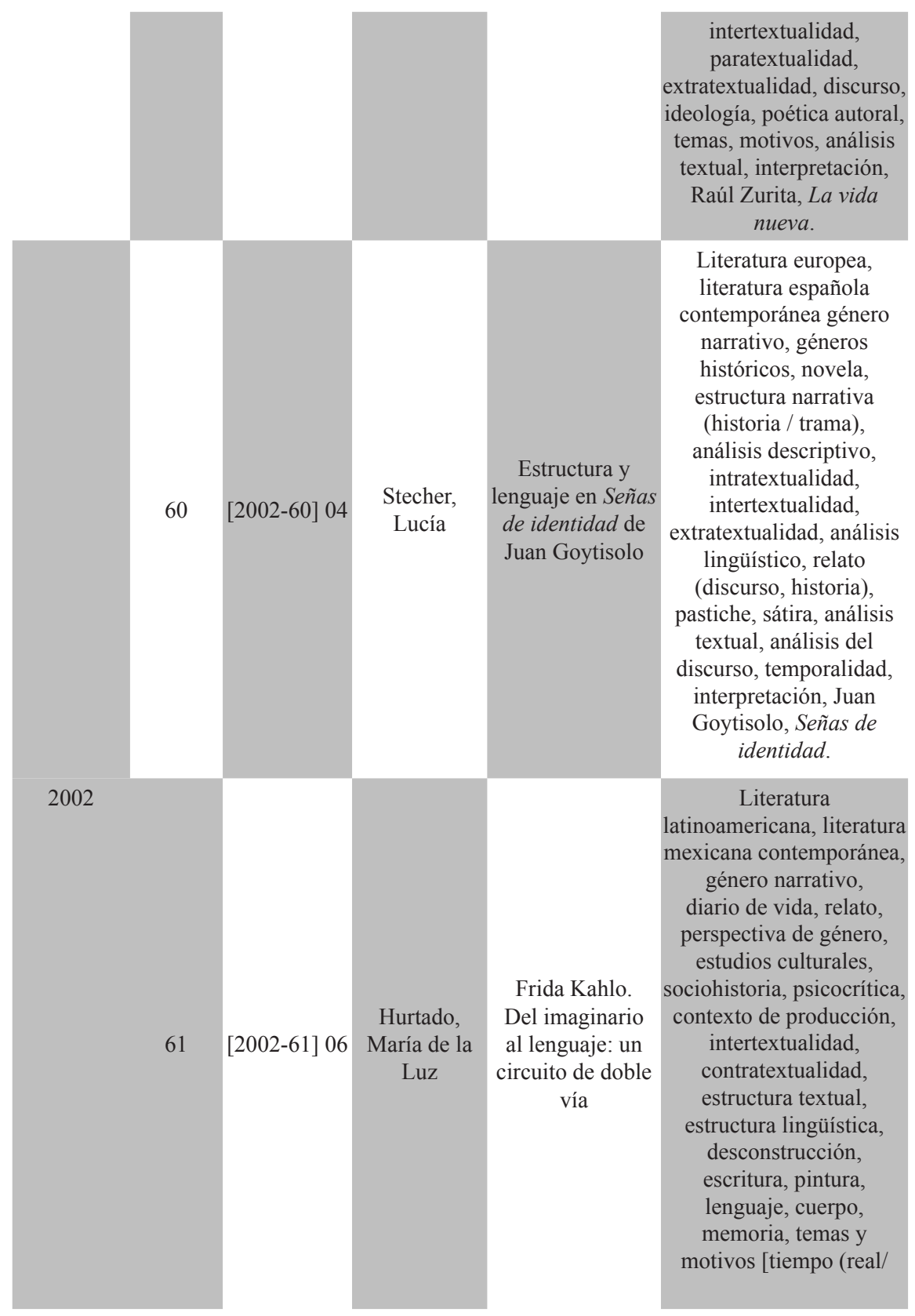




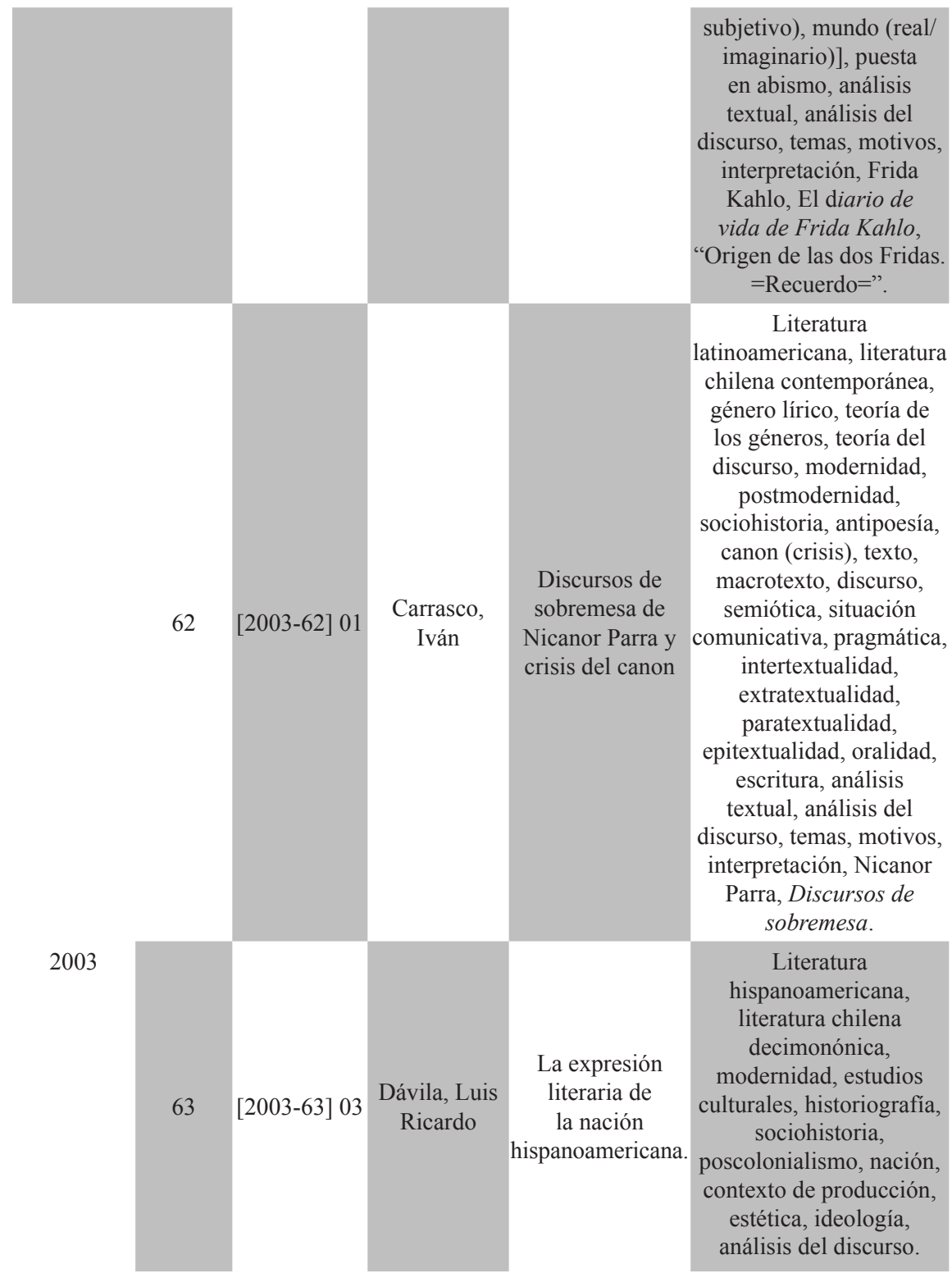




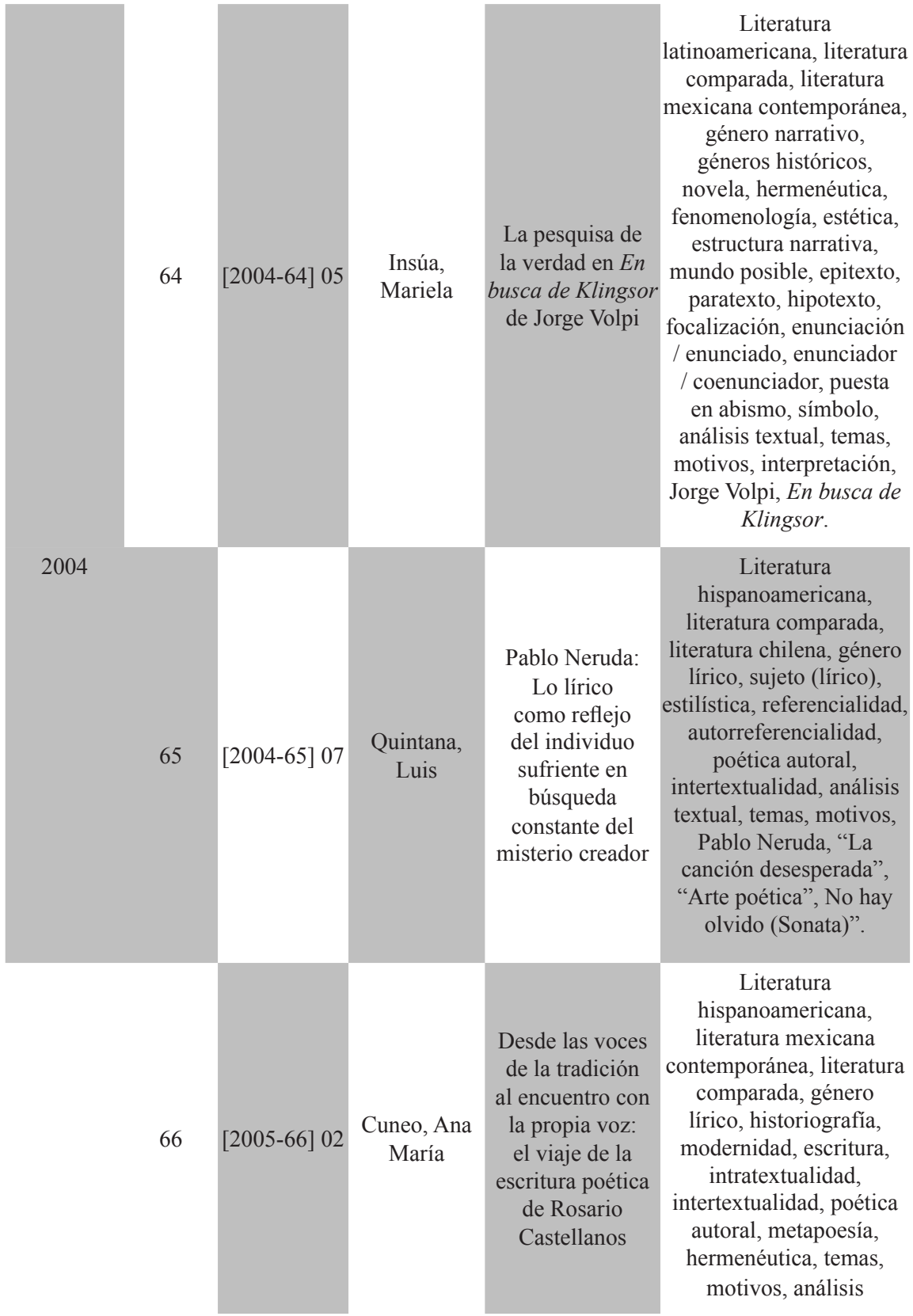




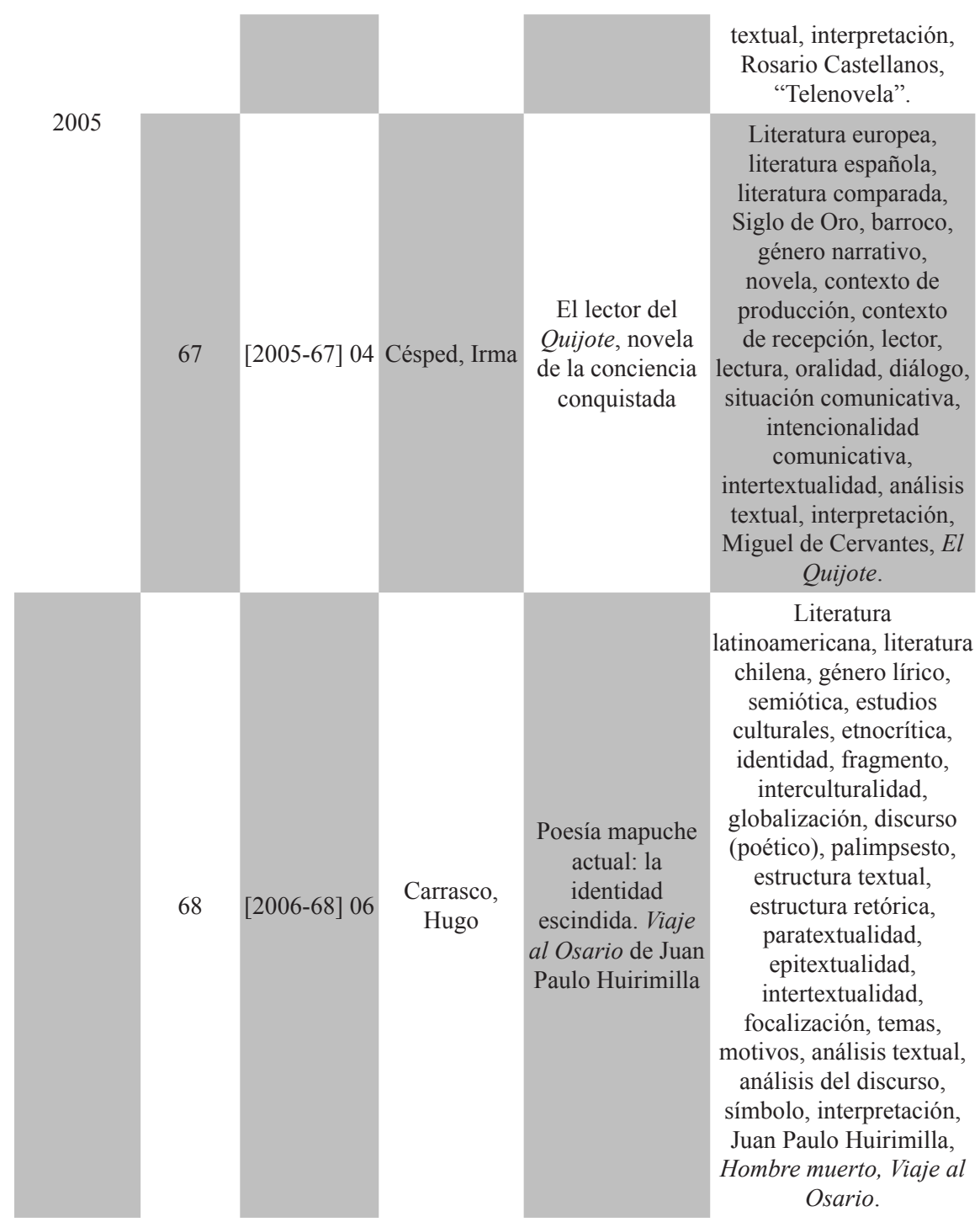




\begin{tabular}{|c|c|c|c|c|c|}
\hline 2006 & 69 & [2006-69] 01 & $\begin{array}{l}\text { Hozven, } \\
\text { Roberto }\end{array}$ & $\begin{array}{c}\text { La ciudad de } \\
\text { Santiago en el } \\
\text { sentir de Joaquín } \\
\text { Edwards Bello y } \\
\text { de Jorge Edwards }\end{array}$ & $\begin{array}{c}\text { Literatura } \\
\text { latinoamericana, literatura } \\
\text { chilena, historiografía, } \\
\text { sociohistoria, género } \\
\text { narrativo, novela, ensayo, } \\
\text { intertextualidad, ciudad, } \\
\text { temas, motivos, análisis } \\
\text { textual, análisis del } \\
\text { discurso, interpretación, } \\
\text { Joaquín Edwards Bello, } \\
\text { El Roto; Jorge Edwards, } \\
\text { cuentos, novelas y } \\
\text { ensayos. }\end{array}$ \\
\hline \multirow[b]{2}{*}{2007} & 70 & [2007-70] 03 & $\begin{array}{l}\text { Candia, } \\
\text { Alexis }\end{array}$ & $\begin{array}{c}\text { El paraíso perdido } \\
\text { de Jorge Teillier }\end{array}$ & $\begin{array}{c}\text { Literatura } \\
\text { latinoamericana, literatura } \\
\text { chilena contemporánea, } \\
\text { género lírico, poesía } \\
\text { lárica, modernidad, } \\
\text { postmodernidad, } \\
\text { paratextualidad, } \\
\text { intertextualidad, } \\
\text { intratextualidad, } \\
\text { poética autoral, mito, } \\
\text { símbolo, tópica, temas, } \\
\text { motivos, análisis textual, } \\
\text { interpretación, Jorge } \\
\text { Teillier. }\end{array}$ \\
\hline & 71 & [2007-71] 02 & $\begin{array}{l}\text { Carrasco, } \\
\text { Rolando }\end{array}$ & $\begin{array}{c}\text { Un mito en } \\
\text { movimiento: } \\
\text { Pablo de Olavide } \\
\text { y su Evangelio en } \\
\text { Triunfo (1797) }\end{array}$ & $\begin{array}{l}\text { Literatura europea, } \\
\text { literatura española, } \\
\text { literatura peruana, } \\
\text { literatura colonial, } \\
\text { literatura comparada, } \\
\text { género narrativo, } \\
\text { géneros referenciales, } \\
\text { historiografía, } \\
\text { poscolonialismo, novela, } \\
\text { contexto de producción, } \\
\text { ideología, mito, temas, } \\
\text { motivos, análisis textual, } \\
\text { interpretación, Pablo de } \\
\text { Olavide, El Evangelio en } \\
\text { triunfo. }\end{array}$ \\
\hline
\end{tabular}




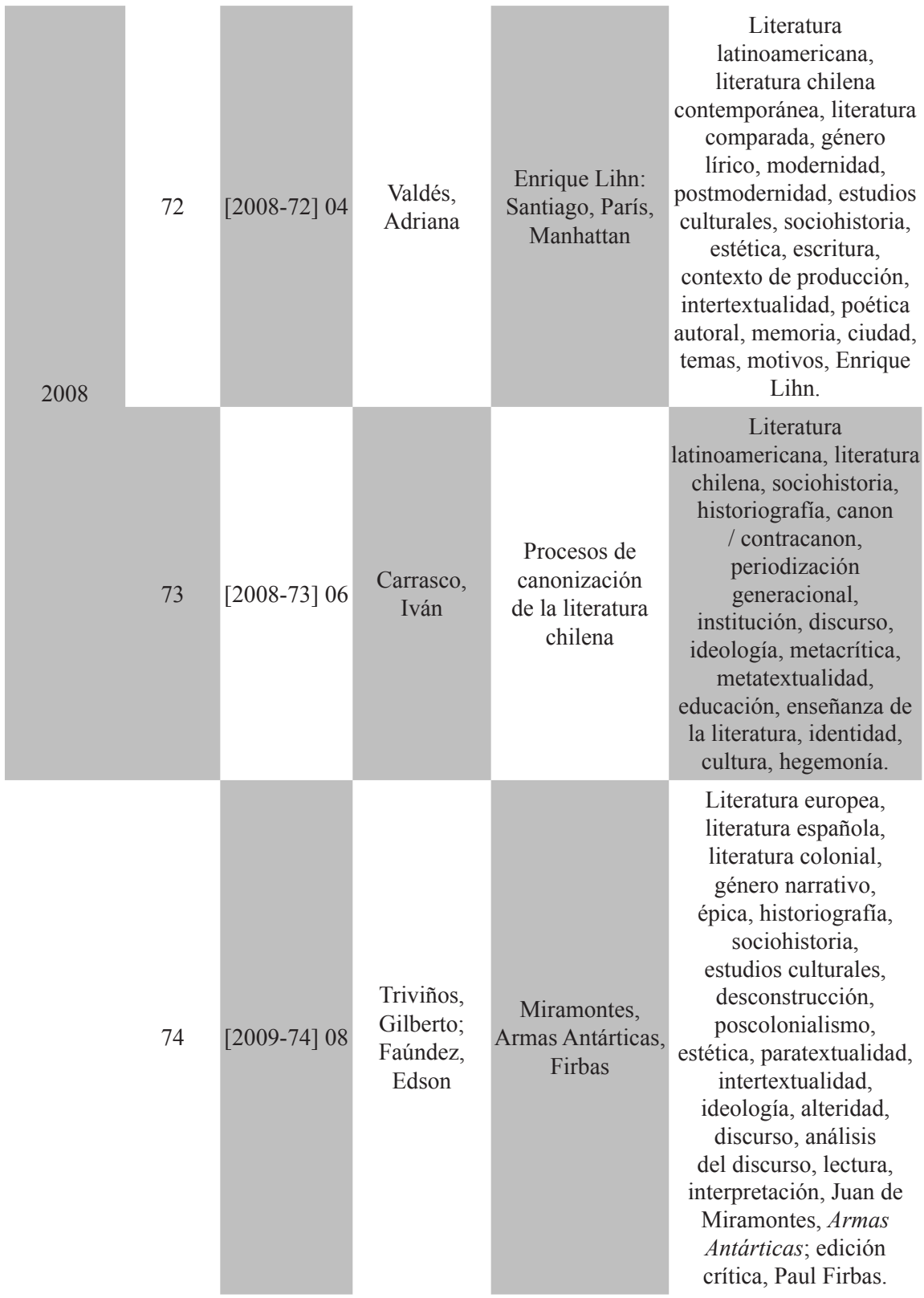


2009

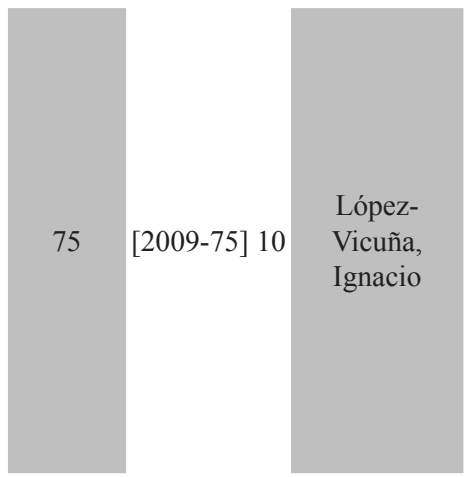

Malestar en

la Literatura:

Escritura y

Barbarie en

Estrella Distante y Nocturno de

Chile de Roberto

Bolaño

\section{Literatura}

latinoamericana, literatura chilena contemporánea, género narrativo, novela, intertextualidad, intratextualidad, discurso, ideología, humanismo / antihumanismo, escritura, poética autoral, temas, motivos, análisis textual, interpretación, Roberto Bolaño, Estrella distante, Nocturno de Chile.

Tabla 3: unidades de registro 1997-2009; fuente: elaboración propia

\section{El T3 ( $\mathrm{N}^{\circ} 51$ al 75 [1997-2009]) exhibe ciertas características que permiten realizar las siguientes afirmaciones (ver Tabla 3.1, inmediatamente a continuación):}

Alteridad, análisis descriptivo, análisis lingüístico, analogía, antipsiquiatría, (auto)referencialidad, barroco, canción, carnaval, cliché, (co)enunciador, contradicción, contratextualidad, crisis de la modernidad, crónica, cuento, cultura, diálogo, diario de vida, edición crítica, educación, enseñanza de la literatura, épica, estilística, estructura lingüística, estructura textual, estructuralismo, etnocrítica, fenomenología, ficcionalidad, filología, fragmento, género dramático, géneros referenciales globalización, hegemonía, hipotexto, homosexualidad, humanismo, imagen, indeterminación, institución, intencionalidad comunicativa, interculturalidad, lector, lenguaje, liberalismo, literatura alemana, literatura argentina, literatura medieval, literatura mística, literatura rioplatense, macrotexto, marxismo, metáfora, metatextualidad, mundo (real, imaginario, posible), nación, neoliberalismo, neovanguardismo chileno, palimpsesto, pastiche, periodización generacional, pintura, poéticas autorales, poshumanismo, postestructuralismo, pragmática, pseudorrealismo, relato especular, retórica (discurso retórico), sátira, semántica, Siglo de Oro, significación, sobredeterminación, sujeto (lírico), teoría de la recepción, teoría del lenguaje, teatralidad, temporalidad, texto, tiempo, tópica, traducción, travestismo, vanguardias. 


\begin{tabular}{|c|c|c|}
\hline 2 & $\begin{array}{l}\text { contexto de recepción, desmitologización, ensayo, enunciación, } \\
\text { enunciado, estructura textual, epitextualidad (epitexto), } \\
\text { existencialismo, focalización, géneros históricos, literatura cubana, } \\
\text { literatura peruana, máscara, matriz textual, memoria, metacrítica, } \\
\text { mito, mundo posible, neobarroco, oralidad, parodia, paradoja, } \\
\text { paratexto, puesta en abismo, relato, situación comunicativa, teoría de } \\
\text { los géneros. }\end{array}$ & 28 \\
\hline 3 & $\begin{array}{l}\text { Extratextualidad, lectura, literatura colonial, literatura } \\
\text { contemporánea, literatura española, literatura mexicana, focalización, } \\
\text { parodia, perspectiva de género, psicocrítica, semiótica, }\end{array}$ & 12 \\
\hline 4 & $\begin{array}{l}\text { Cuerpo, estructura narrativa, literatura hispanoamericana, } \\
\text { hermenéutica, postmodernidad, psicocrítica, símbolo. }\end{array}$ & 7 \\
\hline 5 & $\begin{array}{l}\text { Ciudad, canon, contexto de producción, desconstrucción, } \\
\text { intratextualidad, literatura europea, poesía, poscolonialismo. }\end{array}$ & 8 \\
\hline 6 & Estudios culturales, identidad, modernidad, paratextualidad. & 4 \\
\hline 7 & Estética, identidad, literatura comparada. & 4 \\
\hline 8 & Poética autoral, sociohistoria, & 2 \\
\hline 9 & Escritura, género lírico, ideología. & 2 \\
\hline 10 & Análisis del discurso, historiografía. & 2 \\
\hline 11 & - & 0 \\
\hline 12 & - & 0 \\
\hline 13 & Literatura chilena, modernidad. & 2 \\
\hline 14 & Novela. & 1 \\
\hline 15 & Género narrativo, intertextualidad. & 2 \\
\hline 16 & Literatura latinoamericana. & 1 \\
\hline 17 & - & 0 \\
\hline 18 & Análisis textual, género narrativo, motivo(s), tema(s). & 4 \\
\hline 19 & Interpretación. & 1 \\
\hline 20 & - & 0 \\
\hline 21 & - & 0 \\
\hline 22 & - & 0 \\
\hline 23 & Discurso. & 1 \\
\hline
\end{tabular}

Tabla 3.1: Distribución por frecuencia de conceptos de análisis del T3; fuente: elaboración propia

- Diversificación epistemológica: se produce una apertura de conceptos, métodos, modelos, perspectivas teóricas, que incluyen una amplia gama 
de fenómenos textuales, discursivos, de contexto, ideológicos, culturales, y que instala nuevos objetos, epistemologías y cuerpos disciplinarios heterogéneos y disímiles, algunos de ellos en campos de disputa discursiva e ideológica, que enriquecen, amplifican, profundizan y redistribuyen los estudios literarios, desde las vertientes más tradicionales y conservadoras, hacia nuevos enfoques, temas y modos de comprensión de los fenómenos literarios y sus interrelaciones con teorías emergentes o en régimen, en fase de consolidación, o en etapas terminales; esta apertura puede ser leída como dispersión o como diversificación, dependiendo de cuán estricta, meticulosa o conservadora sea la plataforma de análisis e interpretación que utilicen los autores de los artículos.

- Dominio discursivo: la perspectiva de los estudios del discurso, en sus varias fuentes y modelos, irrumpe con fuerza y se instala sistemáticamente, pues de los 25 artículos del tramo, este concepto aparece utilizado en 23 ocasiones, esto es, en un $92 \%$ de casos. Tanto la teoría del discurso como el análisis del discurso -en cualquiera de sus múltiples y variadas formas y diseños- constituyen un aporte indiscutido en los estudios literarios contemporáneos, pues amplían la observación de fenómenos y objetos que pueden reportarse en la integración de cuerpos disciplinarios de muy amplia índole; para los más puristas, la característica anterior es una desventaja epistemológica (por la imprecisión y la maleabilidad de las filiaciones disciplinarias que convergen como interdisciplinas o transdisciplinas), así como un inconveniente metodológico (por la particularización o atomización de los niveles de análisis lingüísticos que quedan mayoritariamente supeditados a fenómenos extralingüísticos); para quienes utilizan estos conceptos en la formulación de estudios, la característica anterior permite la integración de objetos discretos (textos) en campos de ocurrencia mayores (discursos), permitiendo con ello la explicación e interpretación de rasgos distintivos no vistos en las perspectivas anteriores a los estudios del discurso (van Dijk 1980, 1996, 2009; Wodak y Meyer), así como el cumplimiento de un deber ser ético e ideológico por parte del analista, que, habitualmente compromete su metodología en la defensa o denuncia de desigualdades sociales, culturales, económicas, étnicas, de género, de minorías, etc.

- Anclaje método $\rightarrow$ interpretación: de igual modo, en el T3 se aprecia una metodología que aúna análisis (textual o discursivo), con interpretación, quedando esta última como un efecto de una causa previa. Si bien casi la totalidad de las teorías y sus correspondientes modelos de análisis 
suponen esta premisa en términos históricos, este tramo visibiliza dicha condición en un alto porcentaje de aplicación del método: en 18 ocasiones de 25 (es decir, en un $72 \%$ de los casos), hay presencia de análisis (textual o discursivo) previo a la interpretación del objeto, con 19 ocurrencias en 25 artículos, esto es, en un $76 \%$ de las ocasiones. Ello implica plantear la supremacía metodológica que supone que las interpretaciones se basen en evidencia empírica desde el punto de vista analítico, y no sean constitutivas de apreciaciones fundadas en gustos, preferencias, subjetividades y/o arbitrariedades por parte de los analistas. Esta dinámica es potenciada por herramientas de análisis, conceptos, modelos, marcos epistemológicos y apropiaciones metodológicas que garantizan la solidez, pertinencia y exhaustividad de los sentidos posibles de lecturas presentes en los artículos, a la vez que exhibe una coherente línea de desarrollo con estrategias similares en otros campos disciplinarios (como la misma lingüística, por ejemplo, o los estudios culturales, el feminismo o la perspectiva de género, el poscolonialismo, la psicocrítica, etc.).

- Incremento de la densidad proposicional: el T3 exhibe de modo visible una creciente intensificación en la cantidad de conceptos de análisis e interpretación que conforman la escritura del artículo. Si en el T1 $\left(\mathrm{N}^{\circ} 1\right.$ al 25 [1970 - 1985]), los descriptores del campo 6 (perspectiva teórica, modelo, método, conceptos, objeto) podían tener en promedio, aproximadamente 15 conceptos por artículo, dicha cantidad se incrementó en el T2 ( $\mathrm{N}^{\circ} 26$ al 50 [1985 - 1997]), y se hizo todavía mayor en el T3. El promedio en el T3 es de 22.28 conceptos por artículo, pero la distribución arroja una varianza que fluctúa entre un mínimo de 12 conceptos en la UR [2003-63] 03, versus el máximo de 37 conceptos en la UR [2002-61] 06 . Este incremento en la densidad proposicional de los artículos está en correlación directa con los nuevos enfoques teóricos, pues muchos de ellos no solo acogen conceptos antes no utilizados (cuerpo, antipsiquiatría, máscara, travestismo, poscolonialismo, etc.), sino que también integran conceptos de enfoques anteriores, tradicionales (focalización, hermenéutica, literatura comparada, historiografía, modernidad, etc.), o bien, los plantean en término de revisiones críticas de los mismos (literatura latinoamericana, intertextualidad, estructura textual, relato, teoría de los géneros, etc.). Dicho de otro modo, la densidad discursiva no es efecto inmediato de los nuevos enfoques teóricos adoptados, sino, más bien, de la coenunciación (Mainguenau 21-22) de los mismos en el continuum de 
la teoría literaria contemporánea, fenómeno del cual la $R C h L$ da cuenta fielmente en términos de los procesos de transformaciones discursivas expuestas en sus artículos.

- Redistribución de género por autoría: el T3 también considera una redistribución de las autorías, pues 10 de los 25 artículos fueron escritos por mujeres, esto es un $40 \%$ del tramo, en comparación con el T1, con un $16 \%$, el T2 con un $32 \%$ y el T4 con un $36 \%$. Si bien estos valores pueden expresar variaciones significativas en cuanto a los totales no escrutados de los artículos, indiscutiblemente exhiben una migración correlativa de las autorías y de las participaciones femeninas en la academia, con relación a los estudios literarios. De hecho, solo por colocar un ejemplo de esta redistribución por autoría en su desplazamiento hacia la densidad proposicional de los textos resultantes, los artículos de procedencia femenina (i.e., María de la Luz Hurtado -UR[2002-61] 06- con 37 conceptos; Mariela Insúa -UR [2004-64] 05-con 27 conceptos; Lucía Stecher-UR [2002-60] 04-con 25 conceptos) incorporan proporcionalmente una mayor cantidad de recursos de análisis e interpretación que los de procedencia masculina (i.e., Luis Ricardo Dávila-UR[2003-63] 03-con 12 conceptos; Luis Quintana-UR [2004-65] 07- con 17 conceptos; Alexis Candia -UR [2007-70] 03- con 18 conceptos), demostrando con ello no solo una adecuada y pertinente apropiación de los modelos teóricos que dan origen a dichas nociones, sino también una mayor rigurosidad y exhaustividad en los procedimientos y estrategias analíticas para la elaboración de las consecuentes interpretaciones, incluyendo el uso de plataformas y perspectivas teóricas comunes a ambos géneros de autorías (i.e., literatura hispanoamericana, modernidad, estudios culturales, historiografía, poscolonialismo, nación, contexto de producción, estética, ideología, análisis del discurso, etc.).

- Estandarización de los géneros académicos: otra de las constataciones del T3 es la estandarización del género artículo, documento, estudio o paper, puesto que los textos ya contienen un resumen o abstract, con una síntesis de los mismos, pero en posición final del artículo, es decir, al término de este (2005, $\left.\mathrm{N}^{\circ} 66\right)$. A contar del $\mathrm{N}^{\circ}$ siguiente (2005, $\mathrm{N}^{\circ}$ 67) se incluirá, inmediatamente después del abstract, un conjunto de palabras clave, que actuarán como los metadatos del texto, sobre todo, en las búsquedas de información en bases de datos y en formatos digitales, electrónicos o simplemente web. Posteriormente, el abstract se trasladará al comienzo (2007, N ${ }^{\circ} 71$ en adelante), precediendo al artículo, lo cual permitirá una 
vista panorámica y sintética del texto (Carlino). La estandarización del género paper también incluirá una obligatoria referencia bibliográfica, de acuerdo con una norma, igualmente estándar (MLA Style Manual 2003), así como la regulación del sistema de notas al pie de página, entre otros aspectos formales (Padilla y Carlino, Fuster).

- Instalación de los conceptos de escritura y lectura: en el T3 comienzan a aparecer sistemáticamente dos conceptos, más sus respectivas asociaciones: escritura (9 ocurrencias) y lectura (3 ocurrencias), cuya consolidación se hará visible en el T4 ( $\mathrm{N}^{\circ} 76$ al 98, entre 2010 y 2018). El interés por ambos conceptos proviene, entre otras fuentes, tanto del estructuralismo como del postestructuralismo y la desconstrucción (Culler 1978, 1992), puesto que se trata de la investigación en las materialidades significantes que hacen posible la existencia misma de la literatura y de cualquier teoría que la informe. Sin embargo, estas nociones también existen como cuerpos disciplinarios discretos, tanto en el caso de la escritura (Ducrot y Todorov 228-234) como actividad, como en el caso de las variadas teorías de la lectura (Littau, Mangel). Su aparición, utilización y difusión se corresponden con la ampliación de las bases de observación de los fenómenos y objetos de los que comienza a dar cuenta la teoría literaria en esta transformación discursiva, epistemológica y metodológica, rastreable desde mediados de los 60 hasta la actualidad.

- El filtro ideológico del discurso: otro elemento en circulación para los efectos del análisis de los objetos de estudio es la ideología (Eagleton 1997, van Dijk 2009). Firmemente emparentada a la teoría del discurso (Bernárdez, Foucault, Lotman, van Dijk 1980, 1996), al análisis del discurso (Calsamiglia y Tusón, Lavandera, Lozano et al., Maingueneau, Renkema, Wodak y Meyer), y a las nuevas perspectivas de formulación de estudios, la ideología (9 ocurrencias) contribuye a una mirada más abarcadora de las múltiples dimensiones sociales, culturales, políticas, entre otras, en las que aparecen inscritos los objetos de estudio. Estas dimensiones aportan elementos de juicio que antes eran obliterados, sobre todo si se piensa en el período histórico del T1, con la carga de censura, autocensura y restricciones impuestas por la dictadura, y que incidieron directamente en la vida académica, especialmente en la desarticulación de los sistemas públicos de educación en Chile, muchos de los cuales estaban bajo la tutela de la propia Universidad de Chile, y el Instituto Pedagógico (OCDE 115-116). En este sentido, la integración de perspectivas de análisis que incluyan las variables ideológicas de los 
objetos, permite comprensiones, análisis e interpretaciones de los mismos en niveles superiores de significación.

III.4. Cuarto tRAmo: Nº 76 AL 98 (2010 - 2018)

\begin{tabular}{|c|c|c|c|c|c|}
\hline $\begin{array}{c}\text { Año } \\
\text { publicación }\end{array}$ & $\begin{array}{c}\text { Número } \\
\text { (s) }\end{array}$ & $\begin{array}{l}\text { Numeración } \\
\text { correlativa } \\
\text { del artículo }\end{array}$ & Autoría & $\begin{array}{c}\text { Título } \\
\text { artículo }\end{array}$ & $\begin{array}{l}\text { Perspectiva teórica/área de } \\
\text { estudios, modelo, método, } \\
\text { conceptos, objeto }\end{array}$ \\
\hline & 76 & $\begin{array}{c}{[2010-76]} \\
01\end{array}$ & $\begin{array}{l}\text { Araujo, } \\
\text { Kathya }\end{array}$ & $\begin{array}{c}\text { Configuraciones } \\
\text { de sujeto en la } \\
\text { modernidad } \\
\text { latino- } \\
\text { americana: El } \\
\text { caso de Perú } \\
\text { a inicios del } \\
\text { siglo XX }\end{array}$ & $\begin{array}{l}\text { Literatura hispanoamericana, } \\
\text { literatura peruana, géneros } \\
\text { referenciales, autobiografía, } \\
\text { modernidad, sociohistoria, } \\
\text { estudios culturales, psicocrítica, } \\
\text { contexto, discurso, análisis } \\
\text { del discurso, ideología, sujeto } \\
\text { (configuración), identidad, } \\
\text { pacto social, perspectiva de } \\
\text { género, otredad, individuo, } \\
\text { subjetividad, intersubjetividad, } \\
\text { referencialidad / ficcionalidad, } \\
\text { testimonio, documento, carta, } \\
\text { temas, motivos, José Santos } \\
\text { Chocano, Memorias. Las mil } \\
\text { y una aventuras de Chocano; } \\
\text { Zoila Aurora Cáceres, Mi vida } \\
\text { con Enrique Gómez Carrillo; } \\
\text { Alberto Jochamowitz, Mi } \\
\text { vida profesional. Apuntes } \\
\text { autobiográficos del Ingeniero } \\
\text { Alberto Jochamowitz; Dora } \\
\text { Mayer, Zulen y yo. Testimonio } \\
\text { de nuestro desposorio ofrecido a } \\
\text { la humanidad. }\end{array}$ \\
\hline 2010 & 77 & $\begin{array}{c}{[2010-77]} \\
03\end{array}$ & $\begin{array}{l}\text { Chein, } \\
\text { Diego }\end{array}$ & $\begin{array}{c}\text { Escritores y } \\
\text { estado en el } \\
\text { centenario: } \\
\text { Apogeo y } \\
\text { dispersión de } \\
\text { la literatura } \\
\text { nativista } \\
\text { Argentina }\end{array}$ & $\begin{array}{c}\text { Literatura latinoamericana, } \\
\text { literatura argentina } \\
\text { contemporánea, géneros } \\
\text { referenciales, informe, } \\
\text { historiografía, modernidad, } \\
\text { modernismo, estudios culturales, } \\
\text { contexto, nativismo, estado, } \\
\text { nación, ideología, dispositivo, } \\
\text { política cultural, sujeto, } \\
\text { identidad (nacional), canon, } \\
\text { discurso, análisis del discurso, } \\
\text { idioma nacional, lengua literaria, }\end{array}$ \\
\hline
\end{tabular}




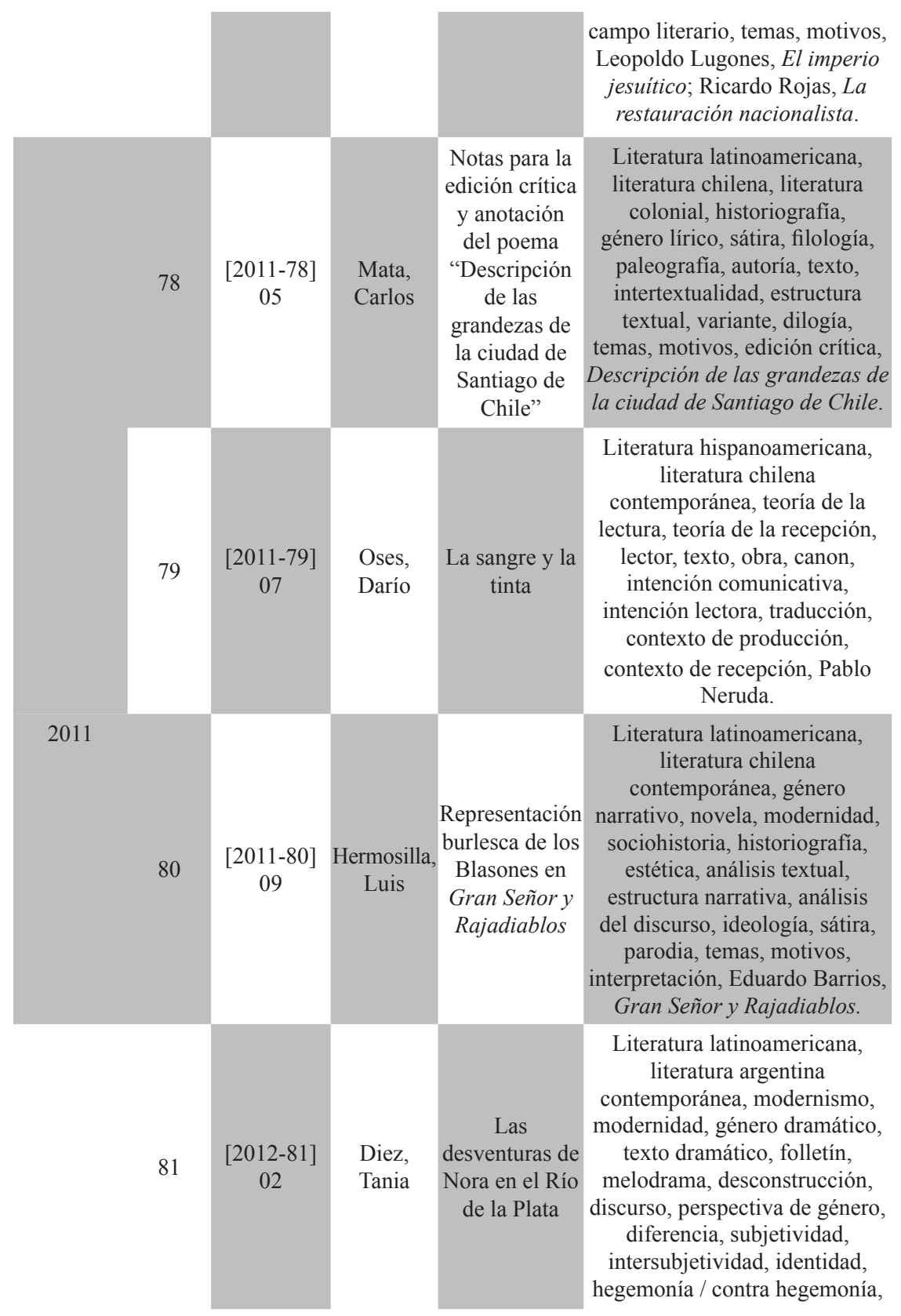




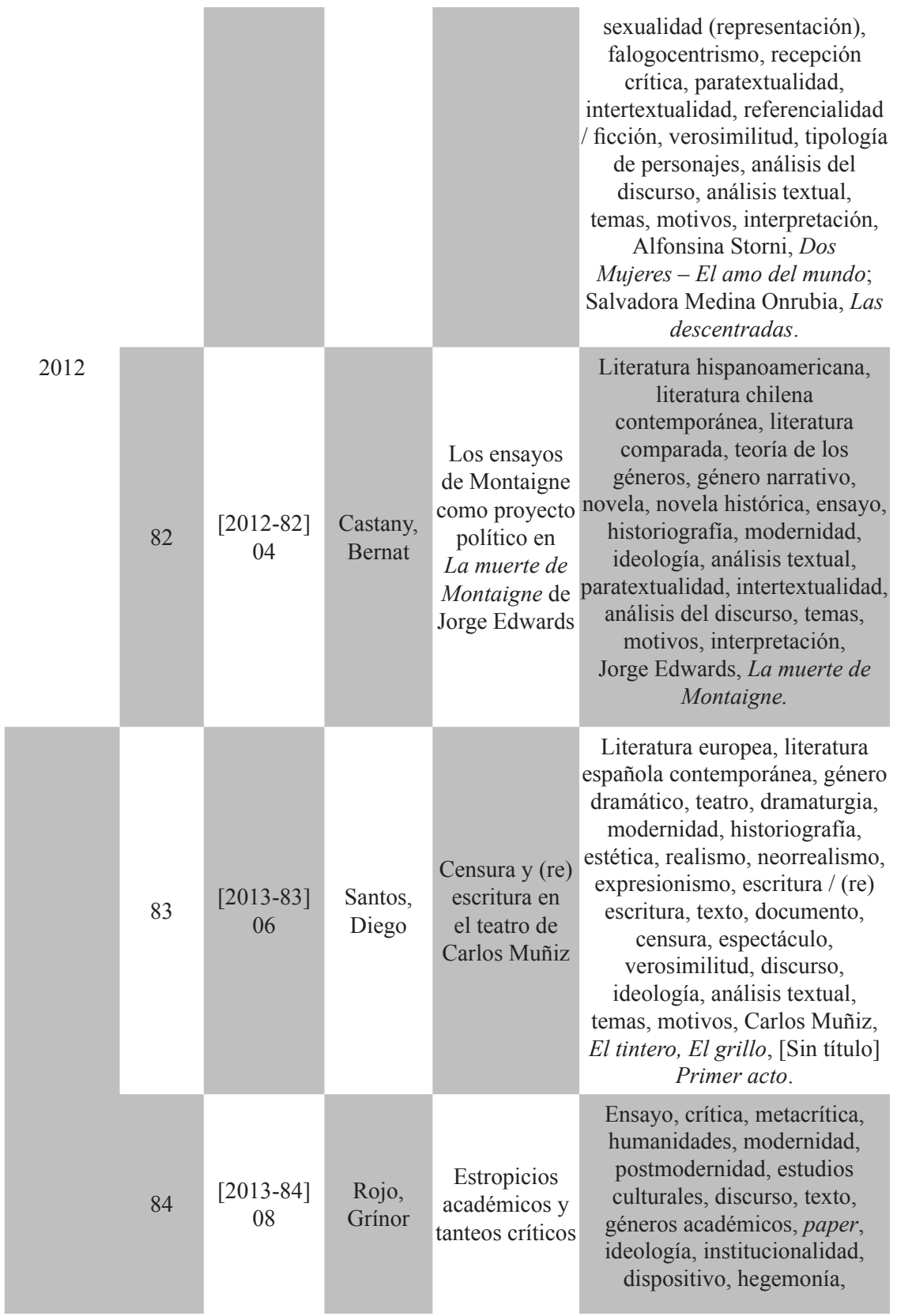




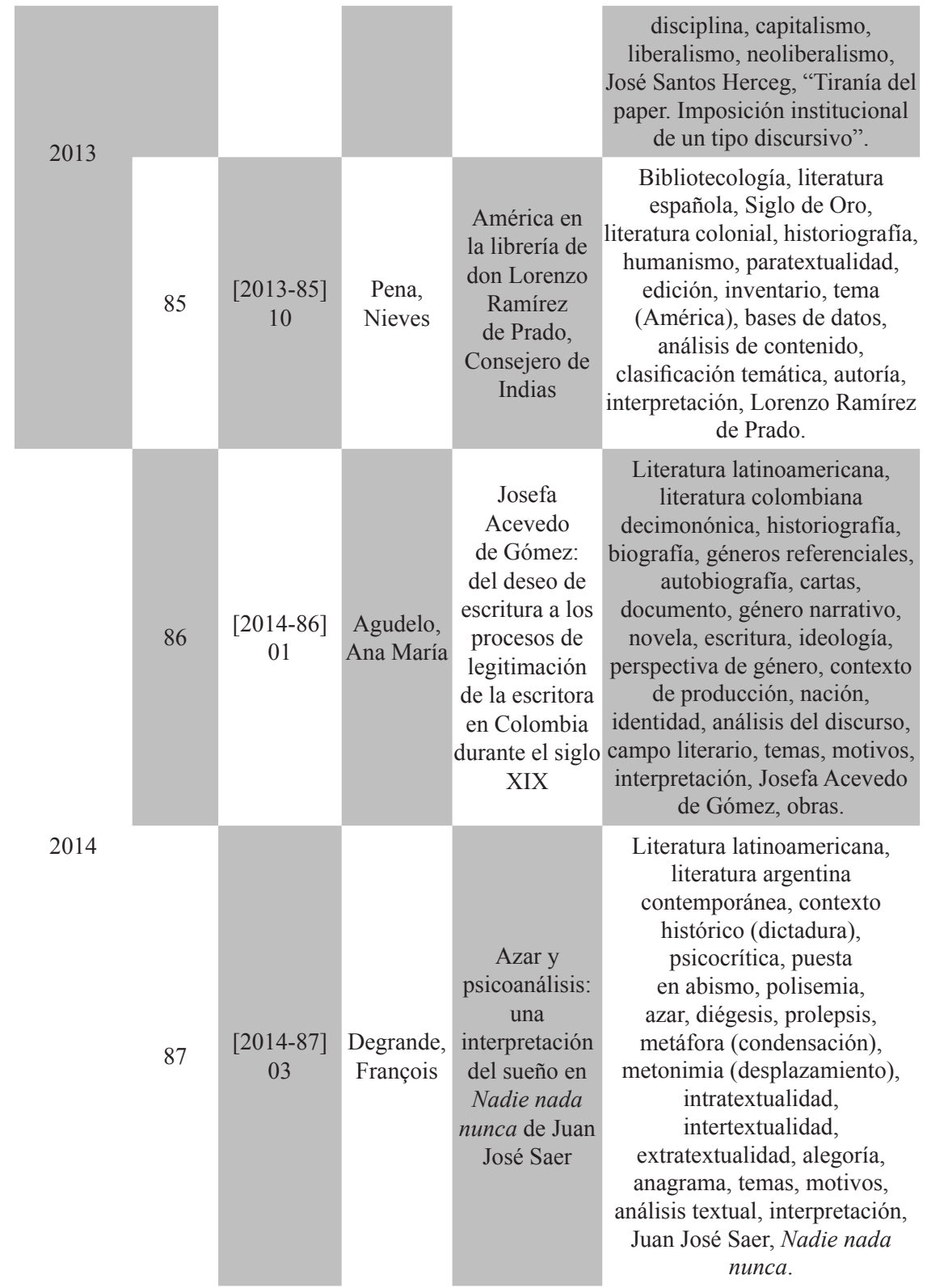




\begin{tabular}{|c|c|c|c|c|c|}
\hline & 88 & $\begin{array}{c}{[2014-88]} \\
05\end{array}$ & $\begin{array}{l}\text { Estupiñán, } \\
\text { Mary Luz }\end{array}$ & $\begin{array}{l}\text { Una escritura } \\
\text { propia. } \\
\text { Anotaciones } \\
\text { sobre literatura } \\
\text { marginal en } \\
\text { Brasil }\end{array}$ & $\begin{array}{l}\text { Literatura latinoamericana, } \\
\text { literatura brasileña } \\
\text { contemporánea, géneros } \\
\text { literarios, géneros musicales } \\
\text { (rap, hip-hop), hibridación } \\
\text { genérica, canon, institución, } \\
\text { centralidad / marginalidad, } \\
\text { historiografía, modernidad, } \\
\text { crítica literaria, metacrítica, } \\
\text { escritura, estudios culturales, } \\
\text { subalternidad, minoría, } \\
\text { producción (cultural, } \\
\text { literaria), consumo / lectura, } \\
\text { representación, estética, } \\
\text { industria editorial, ideología, } \\
\text { testimonio, documento, texto, } \\
\text { referencialidad / ficcionalidad. }\end{array}$ \\
\hline \multirow[t]{2}{*}{2015} & 89 & $\begin{array}{c}{[2015-89]} \\
07\end{array}$ & $\begin{array}{l}\text { Espina, } \\
\text { Eduardo }\end{array}$ & $\begin{array}{c}\text { Neo-No- } \\
\text { Barroco o } \\
\text { barrococó: } \\
\text { Hacia una } \\
\text { perspectiva } \\
\text { menos } \\
\text { inexacta del } \\
\text { neobarroco }\end{array}$ & $\begin{array}{c}\text { Ensayo, literatura } \\
\text { hispanoamericana, } \\
\text { literatura barroca, literatura } \\
\text { contemporánea, género lírico, } \\
\text { historiografía, modernidad, } \\
\text { postmodernidad, estética, } \\
\text { poética, barroco, romanticismo, } \\
\text { neobarroco, discurso, escritura, } \\
\text { canon, paratextualidad, } \\
\text { intertextualidad, metacrítica, } \\
\text { retórica, estilística, temas, } \\
\text { motivos. }\end{array}$ \\
\hline & 90 & $\begin{array}{c}{[2015-90]} \\
09\end{array}$ & $\begin{array}{l}\text { Peralta, } \\
\text { Jorge Luis }\end{array}$ & $\begin{array}{c}\text { Huellas de } \\
\text { disidencia } \\
\text { homoerótica } \\
\text { en } E l \\
\text { Unicornio de } \\
\text { Manuel Mujica } \\
\text { Láinez }\end{array}$ & $\begin{array}{c}\text { Literatura latinoamericana, } \\
\text { literatura europea medieval, } \\
\text { literatura argentina } \\
\text { contemporánea, literatura } \\
\text { comparada, historiografía, } \\
\text { género narrativo, novela, } \\
\text { novela histórica, perspectiva } \\
\text { de género (gay / queer / } \\
\text { homoerotismo), estudios } \\
\text { culturales, estética, contexto } \\
\text { de producción, ideología, } \\
\text { análisis textual, temas, motivos, } \\
\text { interpretación, intratextualidad, } \\
\text { intertextualidad, } \\
\text { extratextualidad, análisis textual, } \\
\text { interpretación, Manuel Mujica } \\
\text { Laínez, El Unicornio. }\end{array}$ \\
\hline
\end{tabular}




\begin{tabular}{|c|c|c|c|c|c|}
\hline & 91 & $\begin{array}{c}{[2015-91]} \\
02\end{array}$ & $\begin{array}{c}\text { Rodríguez, } \\
\text { Mario }\end{array}$ & $\begin{array}{l}\text { Nicanor Parra: } \\
\text { la cueca sola } \\
\text { de "El hombre } \\
\text { imaginario" }\end{array}$ & $\begin{array}{l}\text { Literatura latinoamericana, } \\
\text { literatura chilena, género lírico, } \\
\text { antipoesía, estilística, métrica, } \\
\text { reiteración, paralelismo, } \\
\text { psicocrítica, hipograma, } \\
\text { encriptamiento (cueca sola), } \\
\text { contexto de producción, } \\
\text { referencialidad / ficcionalidad, } \\
\text { análisis textual, temas, motivos, } \\
\text { interpretación, Nicanor Parra, } \\
\text { "El hombre imaginario". }\end{array}$ \\
\hline & 92 & $\begin{array}{c}{[2016-92]} \\
04\end{array}$ & $\begin{array}{c}\text { Garayalde, } \\
\text { Nicolás }\end{array}$ & $\begin{array}{l}\text { Pierre Bayard: } \\
\text { hacia una } \\
\text { crítica policial }\end{array}$ & $\begin{array}{l}\text { Teoría literaria europea, teoría } \\
\text { literaria francesa, metateoría, } \\
\text { crítica literaria, género } \\
\text { ensayístico, género narrativo, } \\
\text { teoría de los géneros literarios, } \\
\text { teoría de la lectura, teoría de la } \\
\text { interpretación, teoría ficcional, } \\
\text { psicocrítica, crítica policial, } \\
\text { marco de referencia, alegoría } \\
\text { de la lectura, contradicción, } \\
\text { enigma, intervención, (des) } \\
\text { estructura textual, mundo } \\
\text { intermediario, concretización, } \\
\text { (in)verosimilitud, (re)escritura, } \\
\text { lectura, (meta)lectura, ficción } \\
\text { / realidad, segregacionismo } \\
\text { / integrismo (lector, } \\
\text { interpretativo), Pierre Bayard, } \\
\text { Qui a tué Roger Ackroyd?, } \\
\text { Enquête sur Hamlet, L'affaire } \\
\text { du chien des Baskerville. }\end{array}$ \\
\hline 2016 & 93 & $\begin{array}{c}{[2016-93]} \\
06\end{array}$ & $\begin{array}{l}\text { Mascioto, } \\
\text { María } \\
\text { de los } \\
\text { Ángeles }\end{array}$ & $\begin{array}{c}\text { Literatura } \\
\text { fantástica } \\
\text { entre el diario } \\
\text { Crítica y } \\
\text { la editorial } \\
\text { Sudamericana: } \\
\text { políticas } \\
\text { editoriales, } \\
\text { materialidad } \\
\text { de los textos } \\
\text { y modos de } \\
\text { escritura }\end{array}$ & $\begin{array}{l}\text { Literatura hispanoamericana, } \\
\text { literatura argentina, traducción, } \\
\text { teoría de los géneros, } \\
\text { géneros históricos, literatura } \\
\text { fantástica, modernidad, } \\
\text { archivo, documento, texto, } \\
\text { contexto de producción, } \\
\text { contexto de recepción, } \\
\text { paratextualidad, intertextualidad, } \\
\text { multimodalidad, medios } \\
\text { de comunicación, políticas } \\
\text { editoriales, escritura / }\end{array}$ \\
\hline
\end{tabular}




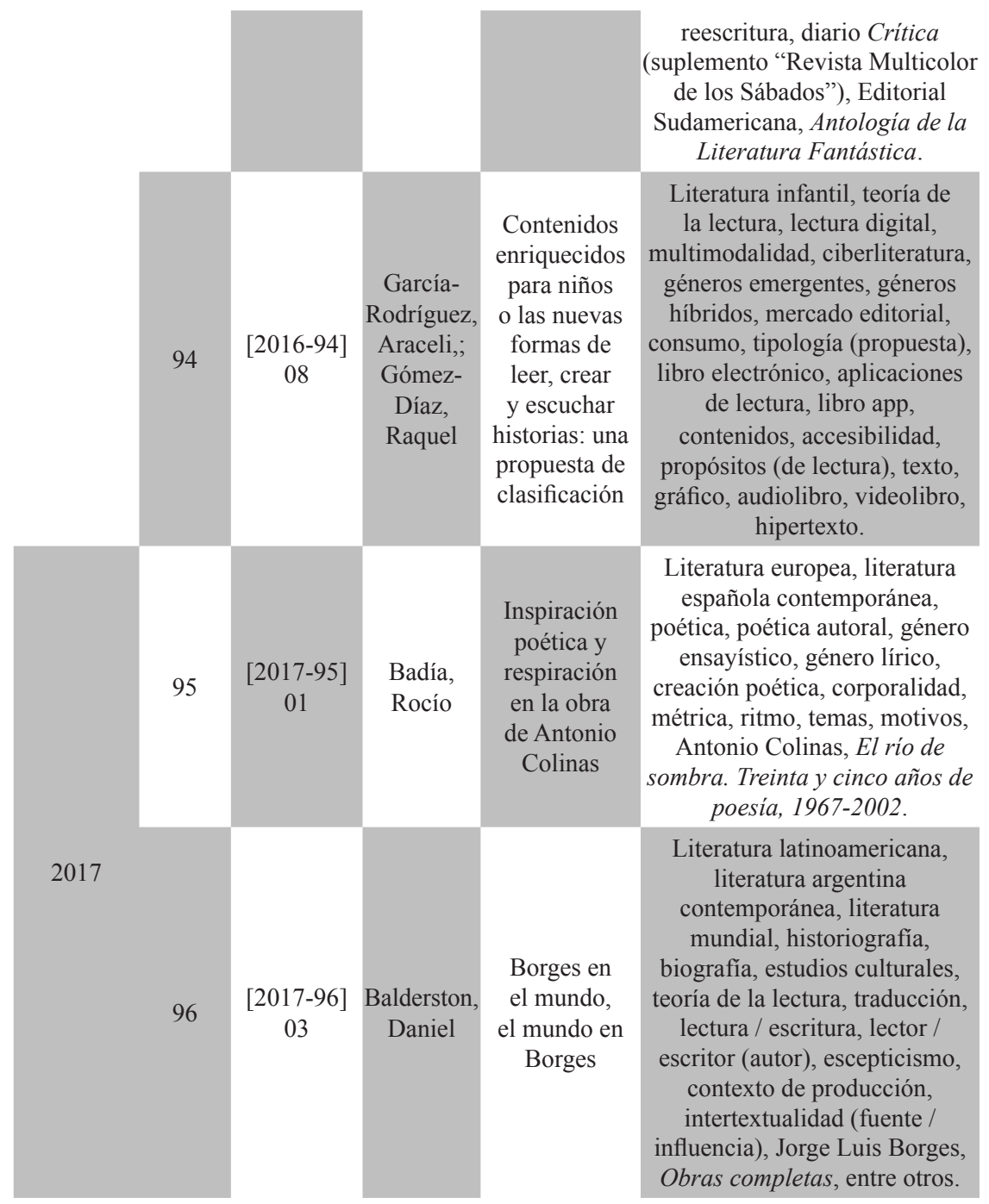




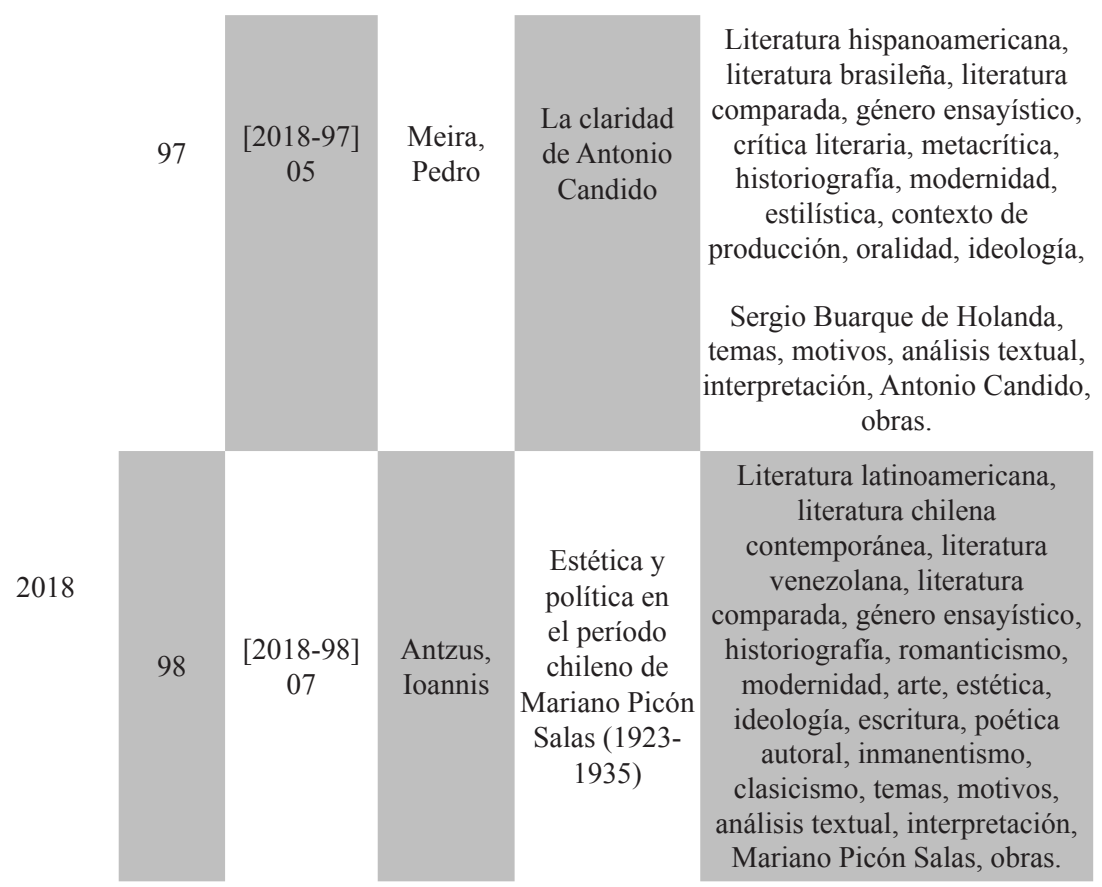

Tabla 4: unidades de registro 2010-2018; fuente: elaboración propia

En este tramo dominan las perspectivas semióticas, esto es, las de análisis del discurso, que portan claros elementos de referencialidad para, así, y desde el texto (Lozano et al., 33-40) (re)configurar lecturas e interpretaciones (UR [2010-76] 01, UR [2012-81] 02, UR [2014-86] 01, etc.). Asimismo, el concepto de ideología aparece, recurrentemente, en varios de ellos, pero no concebido tradicionalmente, sino desde la noción de campo en disputa (Gramsci 14-23) por la hegemonía, tanto desde la incumbencia, como desde las nociones de pretensión y contienda. De esta manera, ingresan a la $R C h L$ artículos que están basados en esta perspectiva (UR [2010-77] 03, UR [2010-77] 03, UR [2012-81] 02, UR [2012-81] 02, UR [2013-83] 06, UR [2014-88] 05, UR [2015-90] 09, etc.). De ahí que, tanto la lectura como la interpretación descansan en una nueva comprensión de la literatura que discute los géneros, no solo los tradicionales (lírica, narrativa y drama), sino también los sexuales (UR [2012-81] 02, UR [2014-86] 01, UR [2014-88] 05, UR [2015-90] 09, entre otros). 
Los estudios culturales latinoamericanos soportan, también, un marco de lectura de las distintas manifestaciones del poder dentro del campo literario: UR [2010-77] 03, UR [2014-88] 05, UR [2017-96] 03, por ejemplo. Así, la noción amplia de transtextualidad, en palabras de Genette (53-62), parece funcionar adecuadamente en esta concepción de la literatura: UR [2011-79] 07, UR [2012-81] 02, UR [2014-87] 03, UR [2015-91] 02, UR [2017-96] 03, etc.

Finalmente, detengámonos en el $N^{\circ} 82$ de la $R C h L$ (2012). José Santos Herceg escribe un artículo titulado "Tiranía del paper. Imposición institucional de un tipo discursivo" (197-217), donde se refiere a la pretensión científica de este último que niega el carácter discursivo y retórico de los textos, algo que para la historia, la filosofía o los estudios literarios ya problematizaron Ricoeur, White o de Man. Además, este tipo de formato se pretende hegemónico frente a la multiplicidad de géneros que tales disciplinas han usado: diálogos, aforismos, cartas, meditaciones, confesiones, biografías, fragmentos, relatos utópicos, exhortaciones o elogios, tratados o summas y el ensayo. La idea de que el conocimiento se produce por acumulación y renovación, produce textos efímeros, sin ninguna hipótesis desarrollada. Se valoran mejor la cantidad y la novedad que lo arriesgado y profundo de la propuesta (un libro vale menos que un paper). Se estaría desoyendo que, como ha afirmado Christiane Schildknecht, hay una "conexión sistemática entre cada concepto del conocimiento o del saber filosófico y la forma (literaria) en que se expresa o se transmite dicho saber" (citada por Herceg, 212).

La $R C h L \mathrm{~N}^{\circ} 84$ (2013), por su parte, se dedica en su totalidad a este problema: Carla Cordua recuerda el carácter ahistórico del cientificismo y afirma que los métodos y pretensiones de la ciencia natural solo son válidos para su área, pero cuando se pretende instaurar a éstos como los únicos modos de conocimiento, lo que se hace es perder el verdadero nexo con la tradición humanista que, en esencia, no es más que aquella que da cuenta del origen histórico del hombre, su relación con el mundo y el resto de la humanidad.

Eduardo Carrasco atribuye una filiación escolástica al modelo científico, aludiendo a aquella época en que el saber implicaba el acuerdo de un conjunto cerrado de personas, y lo opone a la laicidad que debiera propugnar la universidad, entendida ésta como un espacio de comunión que permita enseñar no un saber absoluto y pre-dado sino un no-saber, indispensable para la verdadera inteligencia y la renovación crítica.

Aldo Mazzucchelli plantea el problema poniendo énfasis en la imposibilidad del sujeto en obtener aquel conocimiento libre que le prometía la modernidad, ya sea porque no logra concretarse como objeto de sí mismo y su lectura 
termina (mediante la hegemonía de la desconstrucción y “otras epistemologías de la sospecha") siendo una no-lectura (sin interpretación); o bien, porque la investigación y el destino de las humanidades simplemente no depende de ellas, sino de agentes financieros, y las primeras se han plegado en sus formas de organización a los segundos.

Pablo Chiuminatto critica que la objetividad niegue poseer un estilo, es decir, una condición retórica y entiende que la representación ha de pasar necesariamente por la condición sensible de la mente, esto es, la condición estética del pensamiento.

Teresa Ayala Pérez estudia la producción académica de la revista Anales de la Universidad de Chile en la década del 50, para verificar que la elección de temas y los métodos utilizados constituyen por sí mismos un discurso, el cual muestra una predilección clara por las humanidades, entendidas extensamente (pues alberga textos de historia, filosofía, literatura, arte, folclore, etc.) y por el cultivo del género ensayístico.

Roxana Pey y Pablo Oyarzún entienden la distinción entre el papel verdadero de las humanidades y la mera docencia, es decir, a ésta le falta la conversación, la crítica, la divergencia, la multiplicidad de temas y enfoques para adaptarse a lo humano y cumplir su función democrática y humanista, la que, desligada de ataduras económicas, es ejemplo de una sociedad que no se supedite ella misma a la utilidad y que dé ejemplo de ello con la asunción de lo que ya hace unos años se siente como una inminente gratuidad de la educación.

María Eugenia Góngora recuerda que el paper como género tiene a su vez origen histórico reconocible, de modo tal que es lógico realizar críticas. Recupera tanto la tradición del ensayo latinoamericano, como obras heterogéneas y de largo aliento que dan cuenta de un verdadero pensamiento, por oposición a libros que compilan artículos independientes. El carácter ensayístico, además, está dado por la idea de estilo al que justamente alude el título de un libro de Alberto Paredes sobre el ensayo latinoamericano (El estilo es la idea), en que a su vez resuena la frase de Buffon en su Discurso (1753) sobre el estilo: "el estilo es el hombre". Reconoce para el ámbito humanista el valor de la tradición y la relación íntima que ha de tener el quehacer académico con su contexto inmediato, si quiere producir obras relevantes, al contrario de trabajos que solo busquen la acreditación por parte de la academia metropolitana.

Grínor Rojo, luego de dar cuenta del derrotero mediante el cual las oximorónicamente llamadas "ciencias del espíritu" no hicieron sino plegarse a lo que pretendían atacar, se aboca a criticar por una parte la experticia o 
especialización pretendidamente científica, tecnócrata y burocrática, y por otra, el pretendido carácter transgresor de los "escritores de fragmentos" que profesan ciertos intelectuales postmodernos y postoccidentales. Valora, finalmente, el punto en que las disciplinas van hacia lo externo de ellas para nutrirse y renovar (desde Jakobson y Lévi-Strauss al Barthes postestructuralista) el ensayo desde su origen (Montaigne, Bacon) hasta su expresión contemporánea (Lukács, Adorno, Martín Cerda) como una alternativa seria al inútil aforismo y al inútil paper del experto en nada (UR [2013-84] 08).

Sergio Villalobos compara el régimen de las revistas indexadas con el Index medieval; por su parte, Juan Guillermo Tejeda cree que tal sistema beneficia a los nerd y no a los espíritus verdaderamente creativos. Carlos Ruiz Schneider refuerza la idea de que la crítica en el ámbito del humanismo es fundamental para una sociedad democrática, contra las falsas ideas de utilidad y libertad de autores como Mill o Bentham. José Alberto de la Fuente considera como máxima muestra del proceso de mercantilización de la educación en Chile, el papel obsoleto y secundario que quiere dársele a la literatura en los planes ministeriales, entre otros problemas estructurales.

Hans Ulrich Gumbrecht se centra en Alemania para explicar el daño que políticas estatales causan en el quehacer humanista, básica y esencialmente riesgoso, plural y no metódico, sobre todo a raíz de corroborar que tales programas suelen, por su base cientificista, cuantitativa y totalizante, premiar con dinero y prestigio, no necesariamente a las mejores escuelas, motivando prácticas nocivas que afectan, a su vez, la estructura universitaria.

Adela Cortina valora las humanidades como el estudio de las relaciones intersubjetivas que conforman la sociedad, propiciando un autoconocimiento a partir de las distintas subjetividades que la conforman y de la práctica de una razón cultivada y cuyo uso es público y libre. Javier Zamora Bonilla inserta esta discusión en el panorama adverso de las humanidades en España, pero cree que éstas siguen siendo necesarias al hombre, declarando que la inutilidad que defienden es más aparente que real. Patricia Morodo, en relación con el debate ocasionado por el cierre de departamentos de literatura en E.E.U.U., recuerda, como otros autores de esta revista, la defensa que ha hecho desde The New York Times el profesor Stanley Fish, abogando por el valor intrínseco de las humanidades, a lo que se suman las opiniones de autores como Eagleton o Milliner. Finalmente, Frank Donogue cree que la universidad se ha vuelto un lugar de acreditación para profesionales que trabajan para conglomerados económicos; además, el surgimiento de los community colleges, escuelas de dos años de gran auge en EE.UU., dan cuenta de que las humanidades ya 
no están vinculadas a la idea de Universidad, ni tienen un papel importante en la formación del currículo, por lo que igualar universidad y humanidades no sería pertinente hoy.

La aparición del número monográfico sobre humanidades de la revista Literatura: teoría, historia, crítica (Vol. 17, No 2, julio-diciembre 2015) de la Universidad Nacional de Colombia, Bogotá, está motivada, según expresa declaración de los editores, por el $\mathrm{N}^{\circ} 84$ de la $R C h L$ que hemos comentado. En él no solo aparece la declaración suscrita por varios medios académicos nacionales e internacionales sobre la necesidad de acoger escrituras y soportes textuales divergentes con respecto a los artículos científicos, las prácticas académicas y escriturales, e incluso citacionales, que contaminan el actual mercado del emprendimiento universitario, sino también la preocupación y el interés por intentar dilucidar el rol de los géneros académicos, su inscripción en el ámbito del discurso académico docente, así como su posición relativa con relación a los estudios literarios, las humanidades y la universidad.

\section{BIBLIOGRAFÍA}

Angenot, Marc et al. Teoría Literaria. Articulación histórica de la literatura. México D.F.: Siglo XXI, 1993.

Asensi Pérez, Manuel. Historia de la teoría de la literatura [desde los inicios hasta el siglo XIX]. Valencia: Tirant Lo Blanch, 1998.

Historia de la teoría de la literatura [el siglo XX hasta los años setenta]. Valencia:

Tirant Lo Blanch, 2003.

Barthes, Roland. La aventura semiológica. Barcelona: Paidós, 1993.

El placer del texto y lección inaugural. México D. F.: Siglo XXI, 2015.

Bayer, Raymond. Historia de la estética. México D. F.: Fondo de Cultura Económica, 2000. Bernárdez, Enrique. Introducción a la lingüística del texto. Madrid: Espasa-Calpe, 1982.

Brioschi, Franco y Constanzo di Girolamo. Introducción al estudio de la literatura. Barcelona: Ariel, 2000.

Calsamiglia Blancafort, Helena y Amparo Tusón Valls. Las cosas del decir. Manual de análisis del discurso. Barcelona: Ariel, 1999.

Carlino, Paula. Escribir, leer y aprender en la universidad: una introducción a la alfabetización académica. Buenos Aires: Fondo de Cultura Económica, 2005.

Culler, Jonathan. La poética estructuralista. El estructuralismo, la lingüistica y el estudio de la literatura. Barcelona: Anagrama, 1978.

Sobre la deconstrucción. Madrid: Cátedra, 1992. 
Breve introducción a la teoría literaria. Madrid: Austral / Planeta, 2014.

de Man, Paul. La resistencia a la teoría. Madrid: Visor, 1990.

Dubois, Jean et al. Diccionario de Lingüística. Madrid: Alianza, 1979.

Ducrot, Oswald y Tzvetan Todorov. Diccionario Enciclopédico de las Ciencias del Lenguaje.

México D. F.: Siglo XXI, 1987.

Eagleton, Terry. Una introducción a la teoría literaria. Santafé de Bogotá: Fondo de Cultura Económica, 1994.

Ideología: una introducción. Barcelona: Paidós, 1997.

Estébanez Calderón, Demetrio. Diccionario de términos literarios. Barcelona: Alianza, 2004.

Fernández Fraile, Maximino. Historia de la literatura chilena (I). Santiago: Edebé, 2007.

Historia de la literatura chilena (II). Santiago: Edebé, 2007.

Fokkema, D. y E. Ibsch. Teoría de la literatura del siglo XX. Madrid: Cátedra, 1984.

Foresti, Carlos; Eva Löfquist y Álvaro Foresti. La narrativa chilena. Desde la Independencia hasta la Guerra del Pacífico. Tomo I: 1810-1859. Santiago: Andrés Bello, 1999.

La narrativa chilena. Desde la Independencia hasta la Guerra del Pacifico. Tomo II: Costumbres e historias. 1860-1879. Santiago: Andrés Bello, 1999.

Foucault, Michel. El orden del discurso. Barcelona: Tusquets, 1999.

Franco, Jean. Historia de la literatura hispanoamericana. Barcelona: Ariel, 1987.

Fuster Caubet, Yanet. "El texto académico como género discursivo y su enseñanza en la educación terciaria". Redalyc.org. Abril 2016. https://www.redalyc.org/html/3505/350545716002/

Genette, Gérard. "La literatura a la segunda potencia". En Desiderio Navarro. Intertextualité. La Habana: Criterios, 1997. 53-62.

Gnisci, Armando (ed.). Introducción a la Literatura comparada. Barcelona: Crítica, 2002.

Goic, Cedomil. Historia de la novela hispanoamericana. Valparaíso: Ediciones Universitarias de Valparaíso, 1972.

La novela chilena: los mitos degradados. Santiago: Universitaria, 1997.

Gramsci, Antonio. "Socialismo y cultura”. En Sacristán, Manuel. Antología. México D. F.: Siglo XXI, 1999. 14-23.

Greimas, Algirdas. "Las relaciones entre la lingüística estructural y la poética". Lingüistica y Comunicación. Buenos Aires: Nueva Visión, 1971. 7-21.

Guillén, Claudio. Entre lo uno y lo diverso. Introducción a la Literatura Comparada (Ayer y hoy). Barcelona: Tusquets, 2005.

Iser, Wolfgang. "El proceso de lectura: un enfoque fenomenológico". En Manuel Jofré y Mónica Blanco. Para leer al lector. Una antología de teoría literaria post-estructuralista. Santiago: Ediciones Universidad Metropolitana de Ciencias de la Educación, s/f, 29-51.

Jauss, Hans Robert. "Historia de la literatura como una provocación a la ciencia literaria". En Araújo y Delgado (comp.). Textos de teorías y críticas literarias (del formalismo ruso a los estudios postcoloniales). México D. F.: Ediciones Universidad Autónoma Metropolitana, 2003. 289-296.

Krippendorf, Klaus. Metodología de análisis de contenido. Barcelona: Paidós, 1990. 
Littau, Karin. Teorías de la lectura. Libros, cuerpos y bibliomanía. Buenos Aires: Manantial, 2008.

Lavandera, Beatriz. Curso de lingüística para el análisis del discurso. Buenos Aires: Centro Editor de América Latina, 1990.

Lozano, Jorge; Cristina Peña-Marín y Gonzalo Abril. Análisis del discurso. Hacia una semiótica de la interacción textual. Madrid: Cátedra, 1993.

Lotman, Yuri. La semiósfera (I). Madrid: Cátedra, 1996.

Manguel, Alberto. Una historia de la lectura. Buenos Aires: Emecé, 2005.

Maingueneau, Dominique. Términos claves del análisis del discurso. Buenos Aires: Nueva Visión, 1999.

Marchese, Angelo y Joaquín Forradellas. Diccionario de retórica, crítica y terminología literaria. Barcelona: Ariel, 1989.

Moreno, Mónica y Edwin Carvajal. "El Estructuralismo en literatura: Aportes y límites a las nuevas teorías estéticas y a la investigación en Didáctica de la Literatura”. Enunciación 14-2 (2009): 21-32.

Muñoz González, Luis y Dieter Oelker Link. Diccionario de movimientos y grupos literarios chilenos. Concepción: Universidad de Concepción, 1993.

Organización para la Cooperación y el Desarrollo Económicos (OCDE). Revisión de políticas nacionales de educación. París, traducción y edición en español del Ministerio de Educación de Chile, 2004.

Padilla, Constanza y Paula Carlino. "Alfabetización académica e investigación acción: enseñar a elaborar ponencias en la clase universitaria". En Giovanni Parodi, editor. Alfabetización académica y profesional en el Siglo XXI: Leer y escribir desde las disciplinas. Santiago de Chile: Academia Chilena de la Lengua; Ariel, 2010. 153-182.

Promis, José. La novela chilena actual: orígenes y desarrollo. Buenos Aires: Fernando García Cambeiro, 1977. La novela chilena en el último siglo. Santiago: La Noria, 1993. Testimonios y documentos de la literatura chilena (1842-1975). Santiago: Andrés Bello, 1995.

Rall, Dietrich (comp.). En busca del texto. Teoría de la recepción literaria. México D. F.: Universidad Nacional Autónoma de México, 1987.

Rama, Ángel. La novela en América Latina. Santiago: Ediciones Universidad Alberto Hurtado, 2008.

Renkema, Jan. Introducción a los estudios del discurso. Barcelona: GEDISA, 1999.

Rojo, Grínor; Carol Arcos y Stephanie Massmann. Historia Crítica de la Literatura Chilena (I). Santiago: LOM, 2017.

Segre, Cesare. Principios de análisis del texto literario. Barcelona: Crítica, 1985.

Selden, Raman et al. La teoría literaria contemporánea. Barcelona: Ariel, 2004.

SELGYC (Sociedad Española de Literatura General y Comparada). En: http://www.selgyc. com/index.php/es/ 
Subercaseaux, Bernardo. Historia de las ideas y de la cultura en Chile. Santiago: Universitaria, 1997.

Todorov, Tzvetan (comp.). Teoría de la literatura de los formalistas rusos. México D. F.: Siglo XXI, 2008.

van Dijk, Teun. Estructura y Funciones del Discurso. México D.F.: Siglo XXI, 1980.

Texto y contexto. Semántica y pragmática del discurso. Madrid: Cátedra, 1980.

"Pragmática de la comunicación literaria". En José Antonio Mayoral (comp.),

Pragmática de la comunicación literaria. Madrid: Arco, 1987. 171-194.

La ciencia del texto. México D.F.: Paidós, 1996.

Ideología: una aproximación multidisciplinaria. Barcelona: GEDISA, 2009.

Viñas, David. Historia de la crítica literaria. Barcelona: Ariel, 2002.

Warning, Rainer (ed.). Estética de la recepción. Madrid: Visor, 1989.

Wodak, Ruth y Michael Meyer. Métodos de análisis crítico del discurso. Barcelona: Gedisa, 2003. 